\title{
MAHKEME DIŞI BOŞANMA KURUMU VE TÜRK HUKUKUNUN BU KURUMA YAKLAŞIMI
}

\author{
* Dr. iur. Merve ÜREM ÇETINNEL \\ ${ }^{* *}$ Arş. Gör. Biset Sena GÜNEŞ
}

\begin{abstract}
ÖZET
Boşanma usulü konusunda son ylllarda yaşanan gelişmelerden en önemlisi, anlaşmalı olarak gerçekleştirilmek istenen boşanmalarda eşlere mahkeme dışında, idari makamlar önünde boşanma imkânının verilmiş olmasıdır. Her ne kadar kamu düzeni ve özellikle boşanma sürecinde eşlerin ve çocukların korunması gerektiği düşüncesiyle aleyhinde görüşler ileri sürülmüş olsa da mahkeme dışı boşanma kurumu, mahkemelerin iş yükünü azaltması, eşleri yüksek mahkeme ve avukatlık ücretlerinden kurtarması ve boşanma sürecini hızlandırması gibi sebeplerle uygulaması günden güne artan bir kurumdur. Özellikle Avrupa Birliği ülkelerinin bazılarında son yıllarda bu yönde yasal değişiklikler yapıldığı görülmektedir. Buna karşılık mahkeme dışı boşanma kurumu aile hukuku ilişkilerinin kamu düzenini yakıdan ilgilendirmesi ve boşanma sürecinde hâkimin rolü nedeniyle Türk hukukunda kabul görmemektedir. Ancak ülkemizde gerçekleştirilen boşanmaların önemli bir kısmının anlaşmalı olarak gerçekleştiği göz önüne alındığında, sağladığı avantajlar nedeniyle ileride doğru bir yasal düzenleme ile bu kurumun Türk hukukunda da kabul edilebileceği düşünülebilir. Bu çalışma mahkeme dışı boşanma kurumunu bazı ülke hukuklarından örneklerle ele almakta ve bu kurum karşısında Türk hukukunun mevcut yaklaşımını ortaya koymayı amaçlamaktadir.
\end{abstract}

Anahtar Kelimeler: Aile hukuku, boşanma, anlaşmalı boşanma, mahkeme dışı boşanma, idari makam önünde boşanma.

İstanbul Medeniyet Üniversitesi Hukuk Fakültesi Medeni Hukuk Anabilim Dalı Araştırma Görevlisi, E-mail: merve.cetinel@medeniyet.edu.tr (ORCID ID: 0000-0002-4710-6545).

** Ankara Yıldırım Beyazıt Üniversitesi Hukuk Fakültesi Milletlerarası Özel Hukuk Anabilim Dalı Araştırma Görevlisi, E-mail: bsgunes@ybu.edu.tr, ORCID ID: 0000-0001-8390-6761. (Geliş Tarihi: 15.10.2019 - Kabul Tarihi: 11.12.2019). 


\title{
OUT-OF-COURT DIVORCE AND THE APPROACH OF TURKISH LAW TOWARDS IT
}

\begin{abstract}
The most important development regarding divorce procedure in recent years is that couples have been enabled to divorce out of court, i.e. before administrative authorities, in consensual divorces. Even though there are views against it by virtue of the ordre public consideration and especially by virtue of the consideration that couples and children need to be protected during the divorce process, out-of-court divorce is a phenomenon whose practice is increasing from day to day, since it reduces the caseload before courts, it saves parties from heavy court and attorney fees and it expedites the divorce process. It is seen that legal amendments have been made in this regard particularly in some of the European Union Member States. However, out-of-court divorce is not accepted under Turkish law due to the fact that family relationships are of particular concern to the ordre public and due to the role of the judge in the divorce process. Nevertheless, considering the fact that a substantial part of divorces happening in our country is consensual, out-of-court divorce could also be adopted under Turkish law with a welldrafted legal arrangement in the future because of the advantages it provides. This paper focuses on the concept of out-of-court divorce through examples from different legal systems and aims to propound the current approach of Turkish law towards it.
\end{abstract}

Keywords: Family law, divorce, consensual divorce, out-of-court divorce, divorce before administrative authorities. 


\section{GİRIŞ}

Boşanma kurumunun ülkeden ülkeye değişen çok farklı düzenlemelere konu olduğu noktasında tereddüt bulunmamaktadır. Bazı hukuk sistemlerinde tek taraflı irade beyanıla (genellikle kocanın iradesi) boşanmaya imkân sağlayan dini nitelikli boşanma kurumu uzun yıllardan beri geçerliliğini korurken, bir kısım hukuk sistemlerinde ise boşanmanın yasaklandığı ya da çok ağır şartlara bağlandığı bir sistemden boşanmanın oldukça kolaylaştığı ve reforme edildiği bir sisteme geçilmiştir. Son yıllarda yaşanan ve "boşanma hukukunun özelleştirilmesi (Privatisierung des Scheidungsrechts)"” olarak adlandırılan bu reformlar özellikle iki açıdan söz konusu olmuştur. Bunlardan ilki, maddi hukuk kuralları içerisinde yapılan değişikliklerle boşanma sebepleri konusunda irade serbestisi tanıyan anlaşmalı boşanma kurumunun yerleşmesi şeklinde olmuştur. Bu alanda yapılan ikinci büyük reform ise boşanma usulü açısından olup boşanma konusunda anlaşmaya varan eşlere mahkemeye gitmeden, idari makamlar önünde boşanma hakkının tanınması olarak ortaya çıkmıştır. Aynı şekilde bazı hukuk sistemlerinde boşanma kaynaklı uyuşmazlıklara ilişkin olarak arabuluculuk ve tahkim gibi uyuşmazlık çözüm yöntemlerine başvuru imkânı da kabul edilmiştir. ${ }^{2}$

Bu reformlardan özellikle maddi hukuk açısından Türk hukuku da etkilenmiş, İslam hukukuna dayalı tek taraflı bir boşanma anlayışından ${ }^{3}$ modern

Bräm, Verena (2002) "Privatisierung des Scheidungsrechts - ein Holzweg?": Geiser, Thomas/Koller, Thomas (Hrsg.), Festschrift für Professor Heinz Hausheer zum 65. Geburtstag: Privatrecht im Spannungsfeld zwischen gesellschaftlichem Wandel und ethischer Verantwortung, Bern, Stämpfli Verlag, s. 205 vd.

2 Boşanma usulü konusunda yabancı hukuk sistemlerinde yaşanan önemli gelişmelerden bir tanesi de teknolojik gelişmeler sonucu ortaya çıan "dijital boşanma (digital divorce)" usulüdür. Bu usule göre eşler boşanma sürecine ilişkin bilgi, belge ve anlaşmaları bir dijital platforma kaydetmektedirler. Süreç sonunda tarafların bir araya gelmesine gerek olmaksızın boşanma kararına hükmedilmesi anlamına gelen bu boşanma usulü ile boşanma sürecinin hızlanması, uzayan boşanma süreci sebebiyle eşlerin yıpranmasının önlenmesi ve boşanma masraflarının azaltılması amaçlanmıştır. Dijital boşanma yoluyla boşanmaya hükmedilebilmesi için eșlerin ortak çocuklarının velayeti ve bakımı ile ortak malları konusunda anlaşmış olmaları şarttır. Avrupa ülkelerinden Birleşik Krallık ve Hollanda'da kabul edilen bu boşanma usulü Almanya'da da tartışılmaya başlanmıştır. Dijital boşanmalar hakkında bkz. Güneş Peschke, Seldağ (2018) "Dijital Boşanmaya ilişkin Güncel Düzenlemeler: Farklı Ülke Uygulamaları", Kadem Kadın Araştırmaları Dergisi, C:4, S:1, s. 121-146,

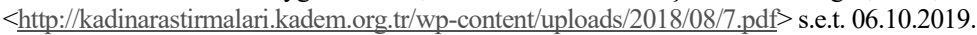

3 Modern hukuktaki boşanma usullerinden önce uygulanmaya başlayan farklı dinler için farklı boşanma usullerinin var olduğunu bilmekteyiz. Buna göre adli boşanmalardan çok daha öncesinde dini boşanmaların var olduğunu söyleyebiliriz (örneğin; Musevi dininde "get"/"geth" olarak adlandırllan boşanmalar). Mahkeme dışı boşanmanın güncel hukuk sistemimizde uygulaması bulunmamakla birlikte, İslam hukukunda ve İslam hukukunun etkisi altındaki Osmanlı Devletinde mahkeme dışı boşanmanın örneklerini bulabilmekteyiz: " $t a$ lak" ve "kuhl". İslam hukukunda kocaya tek taraflı beyanıla (üç kez "boş ol" demesiyle) ve mahkemeye gitmesine gerek olmaksızın evlilik birliğini sonlandırma hakkı tanınmışır. "Talak yoluyla boşanma" adı verilen bu boşanma türünde kendisine mahkeme görevi de yüklenilen kadı, idari makamların katılımı olmaksızın gerçekleştirilen bu boşanmaları şerh etmektedir. Kadının şerh ettiği belge ise mahkeme hükmü gibi kabul görmektedir. Bkz. Saymen, Ferit H. (1950) Aile Hukuku Dersleri, 1949-1950 yllı takrirleri, İstanbul, Teksir 


\section{boşanma sistemine geçiş yapılmış ve hatta taraf iradelerine üstünlük tanıyan} anlaşmalı boşanma kurumu kabul edilmiştir. Boşanma usulü açısından yaşanan gelişmeler ise bir dönem tartışılmış olmasına rağmen Türk hukukunda henüz karşılık bulmamıştır ${ }^{4}$.

Alman hukukunda ve mehaz İsviçre hukukunda olduğu gibi ${ }^{5}$ hukukumuzda da evliliğin hâkim kararıyla son bulması esastır ${ }^{6}$. Buna rağmen farklı ülke-

İşleri, s. 20; Velidedeoğlu, Hıfz Veldet (1954) Türk Medeni Kanununa Göre Medeni Hukuk, Başlangıç- Şahıslar, Aile, Miras ve Eşya Hukuku (Ayni Haklar), İstanbul, İstanbul Matbaacılık, s. 153; Erdem, Bahadır (2006) "Yabancı Aile Hukuku Mahkeme Kararlarının Tanıma ve Tenfizi ile Avrupa Birliği Brüksel II Tüzüğü’: Şıpka, Şükran/Şensöz, Ebru/Şenol, Ayşe Nilay/Özbilen, Arif Barış (Editörler), Uygulamalı Aile Hukuku Sertifika Programı, Medeni Hukuk ve Milletlerarası Özel Hukuk ile İlişkili Güncel Aile Hukuku Meseleleri 18-20 Kasım 2005, İstanbul, İstanbul Ticaret Üniversitesi Yayınları, s. 156; Uyanık Çavuşoğlu, Ayfer (2006) Türk Milletlerarası Özel Hukukunda Boşanma, İstanbul, Beta Yayıncıllk, s. 27-28; Ekși, Nuray (2012) Milletlerarası Özel Hukukta Medeni Olmayan Evliliklerin ve Adli Olmayan Boşanmaların Tanınması, İstanbul, Beta Yayıncılık, s. 42; Akıntürk, Turgut/Ateş, Derya (2019) Aile Hukuku, 21. Baskı, C:2, İstanbul, Beta Yayıncilık, s. 235-236, 238-239.

İslam hukukunda bir diğer boşanma türü ise, "hul"dur (khul, kula). Bu boşanma tipinde kadın kocaya boşanma talebini iletmekte ve boşanma için kocanın bu teklifi kabulü gerekmektedir. Burada evliliklerini sürdüremeyeceklerine inanan kadın ve erkeğin anlaşarak boşanması söz konusudur. Fakat kadının boşanmayı istemesi, evlenme sözleşmesinde kadının erkeği boşayabileceğinin koca tarafindan kabul edildiğinin yer alması şartıyla (tevfiz-i talak) mümkün olacaktır. Boşanma halinde evlenme esnasında verilmiş "mehir"'in kocaya geri verilmesi gerekmektedir. Hul boşanma hakkında bkz. Saymen, s. 20; Velidedeoğlu, s. 153; Köprülü, Bülent/Kaneti, Selim (1985/1986) Aile Hukuku, İstanbul, İstanbul Üniversitesi Hukuk Fakültesi Yayınları, s. 150; Ekși, s. 43. İslam hukukunda anlaşmalı boşanma için bkz. Özdemir, Nevzat (2003) Türk-İsviçre Hukukunda Anlaşmalı Boşanma, İstanbul, Beta Yayıncılık, s. 11-12. Hukukumuzda boşanmaların kazai niteliği (hâkim hükmüyle sona ermesi) dikkate alındığında Türkiye'de talak ile boşanmanın adli boşanmalarla aynı sonucu doğuracağı kabul edilemeyecektir.

4 Ekşi, s. 77. Ancak belirtilmelidir ki son yıllarda yabancı hukuk sistemlerinde yaşanan bu gelişmelerden özellikle boşanma usulüne ilişkin olarak yaşanan gelişmeler dikkate alınarak yabancı ülkelerden alınmış idari nitelikte boşanma kararlarının Türkiye'de nüfus kütügüne tescil edilebilmesi iki yasal düzenleme ile mümkün hale getirilmiştir. Mavi Kartlılar Kütüğü ve Beyan Edilen Nüfus Olaylarının Tutulması Hakkında Yönerge m. 10(3) uyarınca mavi kartlılar kütüğüne kayıtlı kişilerin vatandaşı bulundukları ülke makamlarından almış oldukları karar ve idari belgeler, usulüne göre tasdik edilmiş ve onaylanmışsa doğrudan nüfus kütüğüne tescil edilebilecektir. Aynı şekilde 2017 yılında 690 sayılı Kanun Hükmünde Kararname m. 4 ile Nüfus Hizmetleri Kanunu'na eklenen m. 27/A uyarınca da yabancı ülkelerde idari makamlarca verilen boşanma kararları belirli şartların gerçekleşmesi halinde doğrudan nüfus kütüğ̈̈ne tesciline olanak sağlanmıştır. Bu konuda, özellikle Nüfus Hizmetleri Kanunu'ndaki düzenleme bakımından yapılan değerlendirmeler için bkz. Huysal, Burak (2017) "Nüfus Hizmetleri Kanunu Kapsamında Yabancı Boşanma Kararlarının Doğrudan Tescili", Milletlerarası Hukuku ve Milletlerarası Özel Hukuk Bülteni, C:37, S:2, s. 473-507, Şensöz Malkoç, Ebru (2017) Aile Hukukuna İlişkin Yabancı Kararların Tanınması, İstanbul, On İki Levha Yayıncılık, s. 237 vd., Tütüncübaşı, Uğur (2017) "Yabancı Kararların Türk Hukukunda Tanınması Konusunda 690 Sayılı Kanun Hükmünde Kararname İle Düzenlenen Yenilikler", Dokuz Eylül Üniversitesi Hukuk Fakültesi Dergisi, C:19, S:2, s. 103-128, Ayhan İzmirli, Lale (2018) "Nüfus Hizmetleri Kanunu Madde 27/A Çerçevesinde Yabancı Ülkelerde Verilen Boşanma Kararlarııı İdarî Yoldan Tanınması”, Ankara Hacı Bayram Veli Üniversitesi Hukuk Fakültesi Dergisi, C:XXII, S:4, s. 67-126; Tanribilir, Feriha Bilge (2019) "Türk Hukukunda Yabancı Makamlarca Verilen Boşanma Kararlarının Tanınmasına İlişkin Gelişmeler”, Doğan, Vahit/Ayhan İzmirli, Lale/Yılmaz, Alper Çağrı (Editörler), Milletlerarası Özel Hukukta Güncel Meseleler Sempozyumu, Ankara, Savaş Yayınevi, s. 375-387.

5 Bkz. Art. 111-134 ZGB; § 1564 BGB.

6 Bkz. aşağıda "Boşanma Konusunda Mahkemenin Tek Yetkili Makam Oluşu" başlığı altındaki açıklamalar ve atıflar. 
lerde giderek yaygınlaşan "mahkeme dışı boşanma" kurumumun incelenmesi, boşanma kurumu konusunda yaşanan bu gelişmelerin ve hukukumuzun bu gelişmeler karşısındaki durumunun ortaya konması açısından önemlidir. Bu nedenle bu çalışmada pek çok ülke hukukunda yer bulan mahkeme dışı boşanma kurumu Türk hukuku ile karşlaştırmalı olarak incelenecektir. Çalışmamızda "mahkeme dışı boşanma" kavramı ile eşlerin mahkemeye başvurmaksızın, boşanma ve boşanmanın sonuçları konusunda anlaşarak mahkeme hariç başkaca yetkili makam önünde evlilik birliğini sona erdirmeleri ifade edilmek istenmektedir. $\mathrm{Bu}$ boşanma türünde çoğu zaman eşlerin üzerinde mutabık kaldıkları boşanma anlaşmasını bir idari makam (mesela belediye başkanı veya noter) huzurunda imzalamaları yeterli olmaktadır ${ }^{7}$. Dolayısıyla bu usulde eşler dostane şekilde anlaşarak, ancak mahkeme kararı olmaksızın evlilik birliğini sona erdirmektedir. Öğretide bu kurumu ifade etmek üzere "adli olmayan boşanma", "idari makam önünde/idari makamın katılımı ile boşanma (Scheidung vor einer Behörde/Scheidung unter Mitwirkung von einer Behörde)", "özel boşanma (Privatscheidung)"10 veya "mahkemesiz boşanma (Scheidung ohne Gericht)"11 gibi farklı isimler kullanılmasına rağmen, çalışmamızda Alman öğretisinde sıklıkla tercih edilen "mahkeme dışı boşanma (außergerichtliche Scheidung)" 12 kavramını kullanmayı uygun görüyoruz.

Bu doğrultuda çalışmamızda, dini boşanma usulleri kapsam dışı bırakılarak, ilk olarak genel hatlarıyla mahkeme dışı boşanma kurumu hakkındaki görüşler üzerinde durulacak, ardından mahkeme dışı boşanma kurumuna ilişkin farklı ülke uygulamaları incelenecek, son olarak ise hukukumuzun bo-

Mahkeme dışı boşanma hakkında farklı ülke uygulamaları hakkında bkz. Ekşi, s. 39 vd.; Huysal, s. 476 vd.

Bu yönde bkz. Ekşi.

Rauscher, Thomas (Hrsg.) (2018) Münchener Kommentar zum FamFG, 3. Aufl., München, C.H. Beck, § 107, Rn. 26-28.

10 Ferrand, Frederique (2017) "Stand des Scheidungsrechts in Frankreich": Dutta, Anatol/

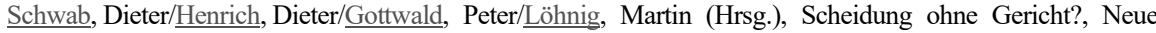
Entwicklungen im europäischen Scheidungsrecht, Bielefeld, Gieseking Verlag, s. 167; Antomo, Jennifer (2018), "Reformbedarf bei der Anerkennung von Privatscheidungen", NZFam, s. 243 vd.; Rauscher, § 107, Rn. 26-28; Heiderhoff, Bettina (2019), Beck'scher Online Kommentar, Bamberger, Heinz Georg/Roth, Herbert/Hau, Wolfgang/Poseck, Roman (Hrsg.), 50. Edition 01.02.2019, EGBGB Art. 17, Rn. 43-45.

11 Bu yönde bkz. Dutta, Anatol/Schwab, Dieter/吕nrich, Dieter/Gottwald, Peter/Löhnig, Martin (Hrsg.) (2017), Scheidung ohne Gericht?, Neue Entwicklungen im europäischen Scheidungsrecht, Bielefeld, Gieseking Verlag.

12 Ferrand, S. 172; Ferrer-Riba, Josep (2017) "Stand des Scheidung in Spanien": Dutta, Anatol/ Schwab, Dieter/Henrich, Dieter/ Gottwald, Peter/Löhnig, Martin (Hrsg.), Scheidung ohne Gericht?, Neue Entwicklungen im europäischen Scheidungsrecht, Bielefeld, Gieseking Verlag, s. 122, 142; Nomer, Ergin (2017) Devletler Hususi Hukuku, 22. Baskı, İstanbul, Beta Yayınc1lk, s. 260; Patti, Salvatore (2017) "Stand des Scheidungsrecht in Italien", Dutta, Anatol/Schwab, Dieter/ Henrich, Dieter/Gottwald, Peter/Löhnig, Martin (Hrsg.), Scheidung ohne Gericht?, Neue Entwicklungen im europäischen Scheidungsrecht, Bielefeld, Gieseking Verlag, s. $105 \mathrm{vd}$. 
şanma konusuna yaklaşımı ve anlaşmalı boşanma kurumunun özellikle hâkimin denetimi boyutu ele alınacaktır.

\section{GENEL OLARAK MAHKEME DIŞI BOŞANMA KURUMU HAK- KINDAKİ GÖRÜŞLER}

Pek çok ülke hukukunda kabul edilen ve uygulaması son yıllarda giderek yaygınlaşmakta olan mahkeme dışı boşanma kurumu öğretide farklı yönlerden ele alınmaktadır.

Bir kısım yazarlar mahkeme dışı boşanma kurumunu olumlu olarak görmekte ve kurumun sağlayabileceği faydaları; boşanma konusunda dostane bir şekilde ortak karar almış eşlerin boşanma davası açarak aile mahkemelerinin iş yükünü arttırmalarının önüne geçmek ve dolayısıyla hâkimleri rahatlatmak ${ }^{13}$, eşleri yüksek mahkeme masraflarından ve avukatlık ücretinden kur$\operatorname{tarmak}^{14}$ ve boşanma sürecini hızlandırmak ${ }^{15}$ şeklinde saymaktadırlar. Aşağıda görüleceği üzere, mahkeme dışı boşanma kurumunu kabul eden ülkelerin çoğunda bu gerekçelerle boşanma usulü açısından böyle bir değişikliğe ihtiyaç duyulmuştur. Mahkeme dışı boşanma kurumunun söz konusu ülkelerde yerleşmesine olanak sağlayan ve aynı zamanda bu kurumun avantajları olarak görülen nedenlerden "eşlerin avukatlık masraflarından kurtarılması" gerekçesi bu boşanma usulünü kullanmak için eşlere avukatla temsil zorunluluğu getirilmesi halinde elbette dayanaktan yoksun kalmaktadır. Ancak avukatların katılımı, eşlerin yönlendirilmesi ve daha adil bir boşanma sürecinin gerçekleştirilmesi açısından önemlidir. ${ }^{16}$ Dolayısıyla avukatların katılımının zorunlu kılınması mahkeme dışı boşanma kurumuna tamamen karşı çıkmak için tek başına bir gerekçe teşkil etmez.

Buna karşılık, öğretide çoğunlukla eşlerin ve özellikle çocukların korunması düşüncesine dayanarak mahkeme dışı boşanma kurumuna karşı çı-

13 Şıka, Şükran (2007) "Hukuk Uyuşmazlıklarında Arabuluculuk Kanunu Tasarısı'nın” Değerlendirilmesi”, İstanbul Ticaret Üniversitesi Sosyal Bilimler Dergisi, C:6, S:12, s. 170; Özbek, Mustafa Serdar (2016) Alternatif Uyuşmazlık Çözümü, C:1, 4. Baskı, Ankara, Yetkin Yayıncılık, s. 284 vd.; Dutta, Anatol (2017) "Stand des Scheidungsrechts in Deutschland": Dutta, Anatol/Schwab, Dieter/ Henrich, Dieter/Gottwald, Peter/Löhnig, Martin (Hrsg.), Scheidung ohne Gericht?, Neue Entwicklungen im europäischen Scheidungsrecht, Bielefeld, Gieseking Verlag, s. 52-53; Ferrand, s. 171.

14 İsviçre'de boşanma davasının yürütülmesi için avukatla anlaşma zorunluluğu bulunmadığına dikkat etmek gerekir. Bkz. Aebi-Müller, Regina/Ziegler, Lenka (2017) "Stand des Scheidungsrechts in der Schweiz": Dutta, Anatol/ Schwab, Dieter/Henrich, Dieter/Gottwald, Peter/Löhnig, Martin (Hrsg.), Scheidung ohne Gericht?, Neue Entwicklungen im europäischen Scheidungsrecht, Bielefeld, Gieseking Verlag, s. 96.

15 Bkz. aşağıda "Farklı Ülke Hukuklarında Mahkeme Dışı Boşanma Uygulamaları" başlığı altındaki açıklamalar ve atıflar.

16 Aynı yönde bkz. aşağıda "Fransa" başlığı altındaki açıklamalar ve atıflar. 
kan bir görüş de bulunmaktadır. Mahkeme dışı boşanma kurumunun bir boşanma usulü olarak kabul edilemeyeceğini savunan yazarlar, boşanma konusunda anlaşma sağlanmış olsa bile eşlerden birinin bu anlaşmanın tarafsız bir kişi veya kurum tarafından kontrol edilmesini isteyebileceğini düşünmektedirler ${ }^{17}$. Ayrıca bu görüş taraftarları, mahkeme dışı boşanmanın kabulü halinde eşlerin hızlıca karar vererek gerek kendilerinin gerekse çocuklarının ihtiyaçlarını gözetmeksizin hareket edebileceklerini ve bu anlamda esasen mahkemelerin bir kontrol mekanizması görevi gördügünü ileri sürmektedirler ${ }^{18}$. Anılan sebeplerin yanı sıra boşanmanın kamu düzenini ilgilendirdiğ $1^{19}$, dolayısıyla eşlerin yalnızca idari makam önünde irade açıklamaları sonucunda boşanmalarının kabul edilemeyeceği ifade edilmiştir.

Türk hukukunda da kamu düzeni düşüncesiyle mahkeme dışı boşanma kurumuna karşı çekinceyle yaklaşılması gerektiği düşünülebilir. Ancak ülkemizde gerçekleştirilen anlaşmalı boşanmaların oranı ve bu boşanmalar açısından mahkeme dişı boşanma kurumunun sağlayacağı faydalar göz önüne alındığında ileride doğru bir hukuki düzenleme ile bu kurumun ülkemizde de kabul edilebileceği kanaatindeyiz. Bu nedenle aşağıda öncelikle örnek teşkil etmesi açısından farklı ülke hukuklarında mahkeme dışı boşanma uygulamalarına değinmek, ardından da genel hatlarıyla Türk hukukundaki durumu incelemek gerekmektedir.

\section{FARKLI ÜLKE HUKUKLARINDA MAHKEME DIŞI BOŞANMA UYGULAMALARI}

Çalışmamızın başında ifade ettiğimiz gibi mahkeme dışı boşanma kurumu bugün için pek çok ülke hukukunda kabul edilmiştir. Bu ülkeler arasında mahkeme dışı boşanma kurumu konusunda tarihsel olarak iki farklı ülke grubu söz konusudur ${ }^{20}$.

\footnotetext{
Dutta, s. 52-53.

Aebi-Müller/Ziegler, s. 79.

Velidedeoğlu, s. 152, 157, 167; Şener, Esat (1977) "Medeni Kanunun Aile ve Nesep Bölümünde Çatışan Eğilimler", Ankara Hukuk Fakültesi 50. Yıl Armağanı 1925-1975, C:2, Boşanma Hukuku Haftası, Ankara, Sevinç Matbaası, s. 234; Dutta, s. 53. Boşanmanın mali sonuçları ve çocukların velayeti konusunun kamu düzenini ilgilendirdiğine ilişkin bkz. Yargıtay 2. Hukuk Dairesi, E: 1989/10658, K: 1990/2000, T: 19.2.1990; Öztan, Bilge (2015) Aile Hukuku, 6. Baskı, Ankara, Turhan Kitabevi, s. 696-698.

20 Antoloskaia, Masha (2016) "Divorce Law in a European Perspective": Scherpe, Jens (ed), European Family Law Volume III - Family Law in a European Perspective, Cheltenham, Edward Elgar Publishing, s. 72-73.
} 
Bunlardan ilkinde mahkeme dışı boşanma kurumu uzun yıllardır uygulanan bir gelenektir ${ }^{21}$. İskandinav ülkelerinden Danimarka, Norveç ve İzlanda'da uygulanan ${ }^{22}$, "İskandinav usulü"23 olarak adlandırılabilecek bu usul, boşanma kurallarının katılığı ve boşanmanın ancak eşlerin evliliğe ilişkin yükümlülüklerini ciddi şekilde ihlal etmeleri sonucunda mümkün olabilmesi gibi nedenlerle uygulamada kralların boşanmaya karar vererek bu kuralları esnetmeleri sonucunda ortaya çıkmıştır ${ }^{24}$. Gerçekten de Kuzey Avrupa ülkeleri yirminci yüzyıl boyunca anlaşmalı boşanmanın kabul edilmesi ve ataerkil toplum yapısının değiştirilmesi konusunda öncülerden olmuşlardır. Bu ülkelerde aile sistemi, diğer ülkelerdekinin aksine toplumun sosyal ve ekonomik güvenliği için gerekli olarak değil, aksine kişisel özgürlüğün, bağımsızlığın, cinsiyet eşitliğinin ve refah devletinin önemini ortaya koyan bir yapı olarak görülmektedir ${ }^{25}$. Bu nedenle bu ülkelerde mahkeme dışı boşanma kurumunun ortaya çıkışının zor olduğu söylenemez.

İkinci grup ülkelerde ise mahkeme dişı boşanma kurumu, boşanma hukukunun adli alandan çıkarılması sürecinin bir parçası olarak uygulanmaya başlamıştır ${ }^{26}$. "Rus usulü" olarak adlandırılabilecek bu ikinci usul, devletin boşanma üzerindeki kontrolünü azaltmak amaciyla 1920'li yıllarda aile hukukunda yapılan büyük reformlarla Rusya'da ortaya çıkmıştır ${ }^{27}$. Son yıllarda özellikle boşanma hukukunun adli alan dışına çıkarılması çalışmaları kapsamında bazı Avrupa Birliği ülkelerinde de mahkeme dışı boşanma kurumunun kabulü konusunda bir eğilim görülmektedir.

Mahkeme dışı boşanma kurumunun kabul edildiği ülkeler, İçişleri Bakanlığı Nüfus ve Vatandaşlık İşleri Genel Müdürlüğü’nün “Yabancı Ülke Adli veya İdari Makamlarinca Verilen Kararların Tescili” konulu ve 06.02.2019

21 Schmidt, T. Svenné (1984) “The Scandinavian Law of Procedure in Matrimonial Causes": Eekelaar, John M./Katz, Sanford N. (eds), The Resolution of Family Conflict - Comparative Legal Perspectives, Toronto, Butterworths, s. 97; Antoloskaia, s. 72.

22 Schmidt, s. 97.

23 Antoloskaia, s. 74.

24 Schmidt, s. 78; Danielsen, Svend (1997) "The Scandinavian Approach: Administrative and Judicial Resolutions of Family Conflicts": Meulders-Klein, Marie Thérèse (ed), Familles et Justice, Brüksel, Bruylant, s. 140; Antoloskaia, s. 73 dn. 186.

25 Sandström Glenn /Garðarsdóttir, Ólöf (2018) "Long-Term Perspectives on Divorce in the Nordic Countries - Introduction", Scandinavian Journal of History, V:48, I:1, s. 1-2.

26 Andrup, Henrik/Buchhofer, Bernd/A. Ziegert, Klaus (1980) "Formal Marriage under the Crossfire of Social Change": Eekelaar, John M./Katz, Sanford N. (eds), Marriage and Cohabitation in Contemporary Societies, Toronto, Butterworths, s. 38; Antoloskaia, s. 72.

27 Antoloskaia, s. 74. 
dağıtım tarihli yazısının 9. ekinde ${ }^{28}$ yer alan listede açıkça görülmektedir. Bahsi geçen listeye göre bu ülkelerden bazıları şu şekildedir: Belarus (ortak çocuk bulunmaması ve mal paylaşımında anlaşmazlık olmadiğı durumlarda belediye, evlilik dairesi gibi evliliği gerçekleştiren kurumlar önünde boşanma), Brezilya (anlaşma olması ve çocuk bulunmaması halinde noterler önünde boşanma), Çin Halk Cumhuriyeti (anlaşma olması halinde evlendirme daireleri önünde boşanma), Danimarka ${ }^{29}$, Fransa ${ }^{30}$, Gürcistan (nüfus kayıt idarelerinde anlaşmalı boşanma), İspanya ${ }^{31}$, İtalya ${ }^{32}$, Japonya (belediye önünde anlaşmalı boşanma) ${ }^{33}$, Kazakistan (idari makamlar önünde anlaşmalı boşanma), Moldova (idari makamlar önünde anlaşmalı boşanma), Norveç ${ }^{34}$, Özbekistan (eşlerin çocuksuz olmaları ve anlaşmaları halinde idari makamlar önünde boşanma), Romanya (idari makamlar önünde anlaşmalı boşanma), Rusya (idari makam önünde anlaşmalı boşanma) ${ }^{35}$.

Aşağıda mahkeme dışı boşanma konusunda farklı ülke hukuklarından bazı örnekler verilmeye çalışılacaktır. Bu kapsamda ilk grupta olan İskandinav ülkelerinden bu kurumu uzun yıllardan beri uygulayan ülkelerden olmaları nedeniyle kısaca Norveç ve Danimarka'daki düzenlemeler incelenecektir. Ardından ikinci grupta olan ve mahkeme dişı boşanma kurumunu son yıllarda yapılan reformlarla kabul etmiş olan ülkelerden olmaları ve hukukumuzun da içerisinde bulunduğu Kıta Avrupası hukuk sisteminden olmaları sebebiyle

$28<$ https://www.nvi.gov.tr/kurumlar/nvi.gov.tr/mevzuat/nufusmevzuat/talimat/06022019tarihlive 17983 sayilitalimat.pdf> s.e.t. 06.10.2019.

Bkz. aşağıda "Danimarka" başlığı altındaki açıklamalar ve atıflar.

Bkz. aşağıda "Fransa" başlığı altındaki açıklamalar ve atıflar.

Bkz. aşağıda "íspanya" başlı̆ı altındaki açıklamalar ve atıflar.

Bkz. aşağıda "İtalya" başlı̆̆ı altındaki açıklamalar ve atıflar.

Japon Medeni Kanunu m. 763 uyarınca Japon eşlere mahkeme dışında boşanma imkânı ("Kyōgi rikon" adı verilen boşanma) verilmiştir. Buna göre boşanma eşlerin boşanma konusunda anlaşmaları ve nüfus müdürlüğünün ilgili aile siciline boşanmayı tescil etmesiyle gerçekleşecektir. Japonya'daki boşanmalarda büyük ölçüde bu yola başvurulmaktadır. Bu boşanma türünde eşlerin boşanmak için yapacakları başvuru eşlerin ve iki tanığın bu formu imzalaması şeklinde olur. Tescil sırasında eşlerin bizzat katılımı ise zorunlu değildir. Eşlerin çocukları varsa boşanma anlaşmasında ayrıca çocuğun boşanmadan sonra velayetinin kimde olacağının da tespit edilmesi gerekecektir. Eşlerin velayet konusundaki anlaşması da boşanmayla birlikte tescil edilecektir. Tescile yetkili makam bu noktada yalnızca şeklen inceleme yapacaktır. Ayrıntılı bilgi için bkz. Trempel, Eberhard J. (2011) "Die Grundzüge des Ehe- und Scheidungsrechts Japans", s. 17 vd., $<$ http://trempel.de/international/japan/ dex.php?TSPD 101 R0=b518cfc4ed66d6deb64c0e6792c9e5bbro70000000000000000e2f20f5fffffo000000 $0000000000000000000005 c e 3 d d 91003 d 2870 f 5>$ s.e.t. 06.10.2019; ayrıca bkz. Motozawa, Miyoko (1989) "Die Ehescheidung in Japan:Ehe und Familie im privaten und öffentlichen Recht", FamRZ, s. 459-465; Uyanık Çavuşoğlu, s. 26-27; Matthew, J. Mccauley (2011) "Divorce and the Welfare of the Child in Japan", Pacific Rim Law \& Policy Journal, V:20, I:3, s. 595-596; Huysal, s. 477, dn. 14; Şensöz Malkoç, s. 301, dn. 695.

34 Bkz. aşağıda "Norveç" başlığı altındaki açıklamalar ve atıflar.

35 Rusya'da noter huzurunda boşanma hakkında bkz. Huysal, s. 477. 
Avrupa Birliği ülkelerinden sırasıyla, İtalya, İspanya ve Fransa örnekleri üzerinde durulacaktır ${ }^{36}$.

\section{A. NORVEÇ}

Norveç hukukunda, boşanma konusunda mahkemeler yanında kralların yetki sahibi olmasıyla ortaya çıan ikili sistem geçerliliğini hala korumaktadır. Bugün için boşanma mahkeme önünde yapılabileceği gibi boşanma konusunda temel yasa olan Evlenme Yasası m. 27 (Lov om Ekteskap) ${ }^{37}$ idari bir usulle vali (fylkesmann) önünde de yapılabilmektedir ${ }^{38}$. Boşanmanın şiddet (Lov om Ekteskap m. 23) veya yakın akrabalar arasında gerçekleşen evlilik ve çok eşlilik nedeniyle (Lov om Ekteskap m. 24) talep edilmesi ya da birlikte yaşamın sona ermesinden sonra iki yıl geçmesi üzerine talep edilmesi (Lov om Ekteskap m. 22) ve boşanma talebinin m. 28 uyarınca vasi tarafından yapılmas1 halinde mahkeme önünde boşanma söz konusu olacaktır ${ }^{39}$. Buradan anlaş1lacağı üzere boşanmanın özellikle önemli sebeplere dayalı olarak çekişmeli bir şekilde gerçekleştiği hallerde mahkeme önünde boşanma söz konusu olacaktır. Zira diğer hallerde boşanma talebi esasen gerçek anlamda bir hukuki problem değildir. Böylece mahkemeler fazladan bir görevden istisna tutulabilir ${ }^{40}$.

Norveç'te uygulamada en çok kullanılan vali önünde boşanma için öncelikle ayrılık usulünün tamamlanması gerekir. Bir başka deyişle eşlerin bu boşanma usulüne başvurabilmeleri için ya eşler arasında evlilik birliğine ara verilmesine karar verilmiş olması ve bundan itibaren bir yıl geçmiş olması ya da bizzat eşler tarafından evlilik birliğine iki yıl boyunca ara verilmiş olması gerekir. Buna rağmen boşanma kendiliğinden gerçekleşmez, eşlerin evlilik birliğini sürdürmek istemediklerini kesin bir şekilde açıklamaları ve bu yönde talepte bulunmaları gerekir. Ortak çocukların bulunması eşlerin bu konuda anlaşmaya varmış olmaları halinde boşanmanın idari usulle gerçekleştirilmesine engel teşkil etmez. Ancak çocukların on altı yaşından küçük olması durumunda Evlenme Yasası m. 26 uyarınca öncelikle arabuluculuk usulüne başvurulması zorunludur. Bunun amacı boşanmadan önce çocuğun menfaatleri,

Mahkeme dışı boşanma hakkında bkz. ayrıca Nomer, s. 259 vd.

LOV-1991-07-04-47: Lov om Ekteskap (ekteskapsloven), I 1991 hefte 12.

38 Kristiansen, Jan Erik (1977) "Norway": Chester, Robert (ed), Divorce in Europe, Leiden, Martinus Nijhoff Social Sciences Division, s. 53; Sperr, Anneken Kari (2017) "Stand des Scheidungsrechts in Norwegen": Dutta, Anatol/Schwab, Dieter/Henrich, Dieter/Gottwald, Peter/Löhnig, Martin (Hrsg.), Scheidung ohne Gericht?, Neue Entwicklungen im europäischen Scheidungsrecht, Bielefeld, Gieseking Verlag, s. 269.

39 Bu yönde bkz. Sverdrup, Tone (2002) "Grounds for Divorce and Maintenance between Former Spouses Norway", s. 4, <http://ceflonline.net/wp-content/uploads/Norway-Divorce.pdf> s.e.t. 06.10.2019.

40 Sperr, s. 269. 
ebeveynlerin sorumlulukları ve çocukla şahsi ilişki kurulması ve çocuğun mutad meskeninin belirlenmesi konularında eşler arasında dostane bir çözüm yoluna ulaşma çabasıdır. Arabuluculuk süreci bir saatle sınırlı olup eşlerin mutlaka bu süreçte anlaşmaları zorunlu değildir. Süreç sonunda sonucu yans1tan bir arabuluculuk belgesi düzenlenir. Bu belge olmadan boşanma sürecine devam edilmesi mümkün değildir ${ }^{41}$.

\section{B. DANIMARKA}

Danimarka'da da Norveç'te olduğu gibi idari otoritelerin boşanma ve aile hukuku alanındaki rolleri tarihte kralların boşanmaya karar verebilmesi anlayışından gelmektedir. Bu tarihsel arka planın sonucu olarak Danimarka hukukunda mahkemeler ve idari otoriteler boşanma ve ilgili diğer konularda aynı anda yetki sahibidir ${ }^{42}$. Uygulamada boşanmalar en çok mahkeme dışı boşanma olarak idari otoriteler önünde gerçekleşmektedir ${ }^{43}$. Bu konuda yetkili makam daha önceleri "devlet idareleri (Statsforvaltningen)" iken, son yapılan değişiklerle 1 Nisan 2019'dan itibaren geçerli olmak üzere "Aile Hukuku Ajansı (Familieretshuset)" olmuştur ${ }^{44}$. Zira evlilikle ilgili hususlar öncelikle bu Aile Hukuku Ajansı tarafından gerçekleştirilmektedir. Boşanmayı isteyen eşler de öncelikle buraya başvurmak zorundadır. Bu anlaşmalı olan ya da olmayan tüm boşanma süreçleri için geçerlidir. Ancak Aile Hukuku Ajansı gerekli görürse, anlaşma sağlanamazsa (şiddet vs. gibi önemli hallerde anlaşma sağlanması çoğunlukla mümkün olmaz) ve taraflar bu karardan memnun olmazsa dosya mahkemeye taşınabilir ${ }^{45}$.

Avrupa Birliği ülkeleri arasında en yüksek boşanma oranlarından birine sahip olan Danimarka'da ${ }^{46}$ boşanma, özellikle 2013 değişikliklerinden ${ }^{47}$ bu yana oldukça hızlı bir şekilde gerçekleştirilebilmektedir ${ }^{48}$. Eşler boşanma ve

$41 \quad$ Sperr, s. 272-273.

42 Danielsen, s. 139; Parkinson, Patrick (2011) Family Law and the Indissolubility of Parenthood, New York, Cambridge University Press, s. 201.

43 Parkinson, s. 201.

44 Lov N. 203 af 05.03. 2019 om ændring af lov om ægteskabs indgåelse og opløsning og lov om Familieretshuset, Børne- og Socialmin., j.nr. 2018-3585. Danimarka'da boşanma kurumuna ilişkin hususlar Evlenme ve Sona Ermesi Yasası (Lov om aegteskabs indgåelse og opløsning)'da düzenlenmiştir.

45 Bu konuda bkz. <https://familieretshuset.dk/en/your-life-situation/your-life-situation/separation-and-divorce> s.e.t. 06.10 .2019 .

$46 \mathrm{Bu}$ yönde bkz. $<$ https://ec.europa.eu/eurostat/statistics-explained/index.php?title=Marriage and divorce statistics\#Fewer marriages.2C more divorces $>$ s.e.t. 06.10.2019.

47 Lov Nr. 647 af 12.06.2013 om ændring af lov om regional statsforvaltning, lov om børns forsørgelse, lov om ægteskabs indgåelse og opløsning og forskellige andre love som følge af ændret organisering af statsforvaltningerne, Økonomi- og Indenrigsmin., j.nr. 2012-01721.

48 Rosenbeck, Bente (2017) “Liberalisation of Divorce”, Scandinavian Journal of History, V:43, I:1, s. 32. 
boşanmanın sonuçları konusunda anlaşmışlarsa ayrılık kararına gerek olmaksızın doğrudan boşanma talebinde bulunabilirler. Eğer anlaşma sağlanamazsa ayrılık kararı talebinde bulunulabilir ve bundan itibaren altı aylık süre geçmeden boşanma talep edilemez (Lov om agteskabs indgåelse og opløsning m. 2930). Ancak boşanma çekişmeli nitelikte olsa bile bazı boşanma sebepleri bakımindan doğrudan boşanma talebinde bulunulabilir. Bunlar zina, iki yıldan fazla süredir anlaşmazlıklar yüzünden ayrı yaşama, eşin diğer eşe veya çocuğa karşı şiddet uygulaması, çok eşlilik hali ve eşlerden birinin ortak çocuğu ya da çocukları kaçırması halidir. Bu boşanma sebeplerinin varlığı halinde boşanma ayrılık kararı talebine gerek olmaksızın doğrudan gerçekleşebilmektedir (Lov om cegteskabs indgåelse og opløsning m. 32-36) ${ }^{49}$.

2019'da yapılan yasal değişiklikle anlaşmalı boşanma talebinde bulunan ve on sekiz yaşından küçük çocukları bulunan eşler için üç aylık bir bekleme süresi zorunlu hale getirilmiştir. Ayrıca eşlerin bu süre içerisinde boşanma sürecinde ve boşanmadan sonra birbirlerine nasıl davranacakları ve çocuklara nasıl yardımcı olacakları konusunda online olarak yürütülen bir kursu tamamlamaları zorunludur (Lov om oegteskabs indgåelse og opløsning m. 42a). Bunun amacı eşleri boşanmadan vazgeçirmek değil, boşanmanın yıkıcı sonuçlarını eşler ve çocuklar açısından en aza indirmektir ${ }^{50}$.

Mahkeme dışı boşanma konusunda son derece liberal düzenlemelerin yer aldığ 1 Danimarka'da boşanma dilekçeleri dahi online olarak eşlerin erişimine sunulmuştur. Eşler anlaşmalı boşanma halinde form şeklinde hazırlanmış bu dilekçeleri doldurarak boşanma talebinde bulunabilirler ${ }^{51}$.

\section{ITTALYA}

Son yıllarda yapılan değişikliklerle mahkeme dışı boşanmayı kabul eden ülkelerden bir tanesi Katolik geleneğine sahip olan ve bu nedenle boşanma kurumunu 1970 yılına kadar reddeden İtalya'dır ${ }^{52}$. İtalya'nın bu konudaki tutumu geçmişte öylesine katıdır ki bunun toplumda ve hukuk sisteminde yarattığı du-

$49 \mathrm{Bu}$ konuda İngilizce olarak yapılmış kısa bir açıklama için bkz. < $\underline{\text { https://familieretshuset.dk/en/your-life- }}$ situation/your-life-situation/separation-and-divorce> s.e.t. 06.10.2019.

50 Bu konuda söz konusu online kursu hazırlama çalışmalarına katılımış olan Prof. Gert Martin Hald (Kopenhag Üniversitesi)'in kısa bir açıklaması için bkz.

$<$ https://www.euronews.com/2019/04/01/denmark-introduces-mandatory-course-for-divorce-seekingcouples> s.e.t. 06.10 .2019 .

51 Formlar için bkz. <https://familieretshuset.dk/en/applications/documents-and-application-forms> s.e.t. 06.10.2019.

52 Bu konuda genel olarak bkz. Saresella, Daniela (2017) "The Battle for Divorce in Italy and Opposition from the Catholic World (1861-1974)”, Journal of Family History, V:42, I:4, s. 401-418. 
rum trajikomik bir olay kurgusu ile 1961 yapımı "İtalyan Usulü Boşanma (Divorzio all'italiana)" ${ }^{\prime 53}$ isimli bir filme bile konu olmuştur. İşte boşanma konusunda uzun yıllar bu denli katı tutum sergileyen İtalya, 2014 yılında yapılan bir reformla boşanma sürecinin hızlandırılması amacıyla mahkeme dışı boşanma kurumunu kabul etmiştir. Buna göre boşanmanın gerçekleşmesi için daha önce kurucu bir şart niteliğinde olan mahkeme kararı artık her koşulda gerekmeyecektir. Eşlerin boşanma ve boşanmanın sonuçları konusundaki irade serbestilerine dayalı bu sistemle birlikte mahkemelerin boşanma konusundaki tekeli sona ermiştir.

İtalya'da daha sonradan bazı ufak değişiklerle kanunlaştırılan ${ }^{54} 132$ sayılı 12.09.2014 tarihli Kanun Hükmünde Kararname ("132 saylı Kararname") ile getirilen bu yeni düzenlemeyle ${ }^{55}$ eşlere bazı şartlar altında avukatların desteğiyle anlaşma yaparak mahkemeye gitmeksizin boşanma imkânı (hızlı boşanma/divorzio veloce - 132 sayl Kararname m. 6) ve avukatların katılımı gerekmeksizin aynı zamanda nüfus işlerinin asıl sorumlusu olan belediye başkanı (Sindaco) önünde idari usulle anlaşmalı boşanma imkânı (132 saylı Kararname m. 12) verilmiştir. Buna karşılık, anlaşmalı olarak boşanmanın mümkün olmadığı durumlarda boşanmak için tek yol mahkemeye başvurmaktır.

Yeni düzenlemeye göre eşler ilk olarak 132 sayılı Kararname m. 6 uyarınca avukatların kendilerini bu usulün süreç ve sonuçları hakkında bilgilendirmesi ve desteğiyle boşanma anlaşması imzalayabilirler. Eşlerin üzerinde mutabık kalmak zorunda oldukları boşanma anlaşmasında, boşanma ve boşanmanın sonuçları, eşlerin çocukları varsa çocuğun bakımı, aile konutunun özgülenmesi, boşanmadan sonra eşlerin çocukla olan ilişkilerinin ne şekilde devam edeceği gibi konuların da düzenlenmesi gerekir. Eşler arasındaki anlaşmada nafaka taleplerine yer verilmesi ise şart değildir. Zira nafaka talep edebilecek eşin nafaka talebinde bulunmaması veya sonraki aşamada nafaka talebinde bulunması mümkündür. $\mathrm{Bu}$ boşanma usulünde eşler arasındaki boşanma anlaşması görevli savcı önüne gelmektedir. Boşanma anlaşmasının savcı kontrolünden geçmesinin temelinde eşler arasındaki muhtemel uyuşmazlıklarda savcının kontrol organı olarak görev yapabileceği düşüncesi yatmaktadır. Eşlerin küçük veya maddi bakımdan kendilerine

53 Germi, Pietro (Yönetmen) (2011), Divorzio all'italiana, Floransa, CG Entertainment.

54 Legge 10 novembre 2014, n. 162, "Conversione in legge, con modificazioni, del decreto-legge 12 settembre 2014, n. 132, recante misure urgenti di degiurisdizionalizzazione ed altri interventi per la definizione dell'arretrato in materia di processo çivile", Gazetta Ufficiale Serie Generale n. 261 del 10-11-2014 - Suppl. Ordinario n. 84. Söz konusu değişikliklerden sonra Kararname metninin son hali için bkz. $<$ https://www.consiglionazionaleforense.it/documents/20182/200991/D.L. + n. $+132-2014>$ s.e.t. 06.10 .2019 .

55 Decreto-Legge 12 settembre 2014, n. 132 "Misure urgenti di degiurisdizionalizzazione ed altri interventi per la definizione dell'arretrato in materia di processo civile", Gazzetta Ufficiale Serie Generale n. 212 del 12 settembre 2014 . 
bağımlı ya da ağır biçimde engelli olan ergin çocukları bulunmaması halinde savcının yapacağ kontrol şekli kontrolden (eşlerin imzalarının tam olup olmaması, anlaşmanın eşlerin avukatları tarafindan imzalanı imzalanmadığı gibi) ibaret$\operatorname{tir}^{56}$. Eşlerin böyle çocukları bulunması halinde ise savcı içerik denetimi yapmakta ve ayrıca yapılan anlaşmada çocuğun menfaatinin korunup korunmadığını denetlemektedir ${ }^{57}$. Şayet savcı yapmış olduğu denetim sonucunda çocuğun menfaatinin korunduğu sonucuna varırsa anlaşmayı onaylayacak ve anlaşmayı tescil edecek olan nüfus memuruna iletecektir. Ancak şunu belirtmek gerekir ki, nüfus kütügüne yapılacak tescil yalnızca açıklayıcı fonksiyona sahiptir ${ }^{58}$. Eşlerin avukatlarının yardımıyla yapmış oldukları, savcı onayından geçmiş boşanma anlaşması mahkeme hükmü niteliğindedir (132 Sayılı Kararname m. $6 f .3)^{59}$.

İtalya'da boşanma konusunda bir diğer yenilik ise eşlerin artık belediye başkanı önünde de boşanabilmeleridir. Bu boşanma usulünün işletilebilmesi eşlerin küçük veya maddi bakımdan bağımlı ya da ağır biçimde engelli olan ergin çocuklarının bulunmaması şartına bağlanmıştır (132 sayıl Kararname m. 12 f. 2). $\mathrm{Bu}$ usul çerçevesinde eşler belediye başkanı önünde ayrılık veya boşanma anlaşması imzalarlar. Yukarıda açıklanan usulden farklı olarak burada avukatların katılımı zorunlu değildir (132 sayılı Kararname m. 12 f. 3 c. 1-2). Belediye başkanı eşlerden ayrılma veya boşanma isteklerini açıklamalarını ister. Bu irade açıklamasından sonra eşlere otuz günlük süre verilir. Verilen bu süre içerisinde eşlerin kararlarını bir kez daha değerlendirmeleri beklenir. Ayrıca verilen süre belediye başkanına eşlerin beyanlarında samimi olup olmadıklarını daha sağlıklı bir şekilde denetleme olanağ 1 vermektedir. Belediye başkanının denetiminden sonra anlaşmanın onaylanması süreci söz konusudur. Burada yapılacak onay, kurucu etkiye sahip olmayıp, yalnızca ispat vasitasıdır ${ }^{60}$.

\section{D. İSPANYA}

Mahkeme dişı boşanma kurumunu son yıllarda yapılan bir reformla kabul eden bir başka ülke de İspanya'dır. Boşanmanın yine Katolik inancı nedeniyle uzun yıllar reddedildiği ancak 1981 yılında çıkarılan bir yasa ${ }^{61}$ ile

56 Cubeddu Wiedemann, Maria Giovanna/Henrich, Dieter (2015) "Neue Trennungs- und Scheidungsverfahren in Italien", FamRZ, s. 1253.

57 Cubeddu Wiedemann/Henrich, s. 1255.

58 Cubeddu Wiedemann/Henrich, s. 1256.

59 Scalzini, Giorgio (2016) "Ehetrennungen und Ehescheidungen auf administrativem Wege in Italien- ein Überblick über die wichtigsten Reformen”, StAZ Das Standesamt, s. 130.

60 Ayrıntılı bilgi için bkz. Cubeddu Wiedemann/Henrich, s. 1253 vd.; Scalzini, s. 129 vd.; Antomo, s. 247.

61 Ley 30/1981, de 7 de julio, por la que se modifica la regulación del matrimonio en el Código Civil y se determina el procedimiento a seguir en las causas de nulidad, separación y divorcio, Boletín Oficial del Esta- 
mümkün hale geldiği bir ülke olan İspanya'da da yıllar içerisinde tüm Batı Avrupa toplumlarında olduğu gibi evliliğin kutsal ve bozulamaz olduğu anlayışından boşanmanın oldukça yaygınlaştığı bir anlayışa geçilmiş ve böylece boşanma sayısında ciddi bir artış yaşanmıştır ${ }^{62}$. Bunun sonucu olarak bu mevcut sosyal gerçekliği hukuki düzenlemelere yansıtmak, mahkemelerde oluşan iş yükünü azaltmak, tarafları dava masraflarından kurtarmak ${ }^{63}$ ve uzayan boşanma süreci nedeniyle yaşanan aile içi şiddet vakalarının önüne geçebilmek amacıyla $^{64} 2005$ yılında çıarılan yasa ${ }^{65}$ ile "hızlı boşanma (divorcio exprés)" 66 olarak adlandırılan boşanma usulü getirilmiştir. Buna göre eşlere evliliğin gerçekleşmesinden itibaren üç ay geçtikten sonra sebep göstermeksizin boşanma talebinde bulunma hakkı verilmiştir (Código Civil m. 81 f. 2 ve m. 86). Dolayısıyla eşlerin tek taraflı da olsa mahkemeye başvurarak boşanma iradelerini bildirmeleri evlilik birliğinin temelden sarsılmış olduğunu göstermeye yeterli kabul edilmiştir ${ }^{67}$.

İspanya'da boşanmanın yasal olarak kabul edilmesi ve daha sonra boşanmaya ilişkin kuralların esnetilmesi ile başlayan sürecin son aşamasında 2.7.2015 tarihli 15/2015 sayılı yasa ${ }^{68}$ ile adli hizmet memuru (Secretario juidicial) veya noter önünde boşanma kurumu kabul edilmiştir. Bu usule göre boşanmanın gerçekleşebilmesi için iki temel şart söz konusudur (Código Civil m. 82 f. 2 ve 87). Öncelikle eşlerin boşanma ve boşanmanın sonuçları hakkında tümüyle anlaşmış olmaları gerekir. Eğer eşler arasında bu konularda anlaş-

do núm 172, de 20 de julio de 1981, s. 16457-16462. Bu yasadaki düzenlemeler hakkında ayrıntılı bilgi için bkz. Glos, George E. (1983) “The Spanish Divorce Law of 1981”, International and Comparative Law Quarterly, V:32, I:3, s. 667-688.

62 Martin-Casals, Miquel/Ribot, Jordi (2008) "The Postmodern Family and the Agenda for Radical Legal Change in Spain": Atkin, Bill (ed), The International Survey of Family Law 2008 Edition, Bristol, Jordan Publishing, s. 425.

63 Bu gerekçeler özellikle yasa çıkarılmadan önce yapılan reform çağrılarında vurgulanıyordu. Bu konuda örnek olarak İspanya Aile Hukuku Avukatları Derneği (Asociación Española de Abogados de Familia)'nin görüşleri için bkz. Martin-Casals, Miquel/Ribot, Jordi/Sole, Joseph (2002) "Grounds for Divorce and Maintenance Between Former Spouses - Spain”, s. 7 dn. 13, <http://ceflonline.net/wp-content/uploads/SpainDivorce.pdf> s.e.t. 06.10.2019.

64 Ferrer-Riba, Josep (2006) "Same-Sex Marriage, Express Divorce and Related Developments in Spanish Marriage Law", International Family Law, s. 142.

65 Ley 15/2005, de 8 de julio, por la que se modifican el Código Civil y la Ley de Enjuiciamiento Civil en materia de separación y divorcio, Boletín Oficial del Estado núm 163, de 9 de julio de 2005, s. 24458-24461.

$66 \mathrm{Bu}$ nedenle söz konusu yasa "hızlı boşanma yasası (ley del divorcio exprés)" olarak adlandırılmaktadır. Bu yönde örnek olarak bkz. Ferrer Ortiz, Javier (2011) "Del Matrimonio Canónico Como Modelo al Matrimonio Civil Deconstruido: La Evolución de la Legislación Española", Revista Ius et Praxis, V:17, I:2, s. 414

67 Ferrer-Riba, Josep (2012) "Marital Agrreements and Private Autonomy in Spain": Scherpe, Jens (ed), Marital Agreements and Private Autonomy in Comparative Perspective, Oxford and Portland, Oregon, Hart Publishing, s. 354.

68 Ley 15/2015, de 2 de julio, de la Jurisdicción Voluntaria, Boletín Oficial del Estado núm 158, de 03 de julio de 2015, s. 54068-54201. 
mazlık varsa boşanma ancak mahkeme önünde, çekişmeli olarak gerçekleştirilebilecektir. Eşlerin bu usule göre boşanabilmeleri için ikinci şart ise küçük veya bağımlı çocuklarının (örneğin; aynı evde yaşayan ve yardım olmaksızın hayatını idame ettiremeyecek çocuklar) bulunmamasıdır. Böyle bir durumda çocukların menfaatlerinin korunması ve onların dinlenebilmesi ancak savcı aracılığıyla mahkeme önünde gerçekleştirilen boşanma usulünde söz konusu olabileceği için mahkeme dışı boşanmaya izin verilmemiştir ${ }^{69}$.

$\mathrm{Bu}$ şartların gerçekleşmesi halinde eşler boşanma yönünde iradelerini adli hizmet memuru veya noter önünde açıklayabilirler. Her ikisi de boşanma konusunda aynı derecede yetkilidir. Uygulamada hızlı olması, daha az bürokratik olması, kolay erişilebilmesi ve çok ciddi bir masraf olmadan karar alınabilmesi nedeniyle daha çok noterler tercih edilmektedir ${ }^{70}$.

\section{E. FRANSA}

Mahkeme dışı boşanma kurumunun yakın zamanda kabul edildiği bir diğer ülke Fransa'dır. Fransız hukukunda 1975 yılında yapılan bir reformla kabul edilen anlaşmalı boşanma ${ }^{71}$ zaman içerisinde oldukça yaygınlaşmıştır. Özellikle 2004 yılında yapılan değişiklikle daha önce var olan boşanma anlaşmasının iki kez hâkim kontrolünden geçmesi ve evliliğin üzerinden altı ay geçmesi şartlarının yerine, eşlere yalnızca bir kez hâkim önüne giderek ve altı ay beklemeksizin anlaşmalı bir şekilde boşanma hakkı verilmesiyle bu tür boşanmaların sayısı $\operatorname{artmıştır~}^{72}$. Fransız Milli İstatistik Enstitüsü ve Ekonomi Çalışmaları (Insee)'nın verdiği rakamlara göre, 2016 yılında gerçekleştirilen 128.000 boşanmanın yarısından fazlası anlaşmalı boşanma şeklinde gerçekleştirilmiştir $^{73}$. Buna rağmen, Fransız aile hâkimleri ciddi bir iş yüküyle karşı karşıya kalmış ve boşanma sürecinde hem zamansal hem de ekonomik olarak kayıplar yaşanmıştır ${ }^{74}$. Öte yandan, toplumsal ilişki ve ihtiyaçların değişmeye

$69 \quad$ Ferrer-Riba (2017), s. 131-132.

70 Ferrer-Riba (2017), s. 135.

71 Loi n ${ }^{\circ}$ 75-617 du 11 juillet 1975 portant réforme du divorce, Journal Officiel de La République Française ${ }^{\circ}$ 0161,12 julliet 1975 .

72 Loi n $^{\circ} 2004-439$ du 26 mai 2004 relative au divorce, Journal Officiel de La République Française n ${ }^{\circ}$ 122, 27 mai 2004.

73 Bu yönde bkz. <https://www.insee.fr/fr/statistiques/3676592?sommaire=3696937\&q=divorce\#titre-bloc-3> s.e.t. 06.10 .2019 .

74 Biland, Émilie/Steinmetz, Hélène (2017) “Are Judges Street-Level Bureaucrats? Evidence from French and Canadian Family Courts", Law \& Social Inquiry, V:42, I:2, s. 306 vd.. Benzer yönde bkz. Özcan, Cem (2019), "Fransız Hukukunda Mahkeme Dışı Anlaşmalı Boşanma”, Legal Hukuk Dergisi, C:17, S:194, s. 648. 
başlamasıyla anlaşmalı boşanma usulünün mahkeme dışına taşınması ihtiyacı ortaya çıkmıştır ${ }^{75}$.

Tüm bu gelişmeler sonucunda eşlerin boşanma konusunda anlaşmalarından sonra artık mahkeme sürecinin gereksiz olduğu düşüncesi ortaya çık$\mathrm{miş}^{76}$ ve daha önce teklif edilmesine rağmen reddedilen mahkeme dişı boşanma kurumu ${ }^{77}$, 18.11.2016 tarihli ve 2016-1547 sayılı Kanun m. 50 78 ile kabul edilmiştir. 1 Ocak 2017 tarihinde yürürlüğe giren bu boşanma usulüne göre eşler, evliliği bitirme ve bunun sonuçları konusunda anlaşmaya vardıktan sonra bu anlaşmalarını yazılı bir belge haline getirerek imzalarlar. Boşanma anlaşması ayrıca avukatlar tarafından da imzalandıktan sonra noter tarafından tutulan sicile tescil edilir. Bu tescil ile boşanmanın gerçekleştirildiği tarih tespit edilmiş olur ve boşanma anlaşması icrai etki kazanır (Code Civil m. 229-1).

Fransız hukukundaki mahkeme dışı boşanma kurumuna bakıldığında bu boşanma sürecinin sözleşmesel nitelikte olduğu görülmektedir. Buna göre yapılacak boşanma anlaşması, geçerli bir sözleşmenin özelliklerini taşımalıdır ${ }^{79}$. Ayrıca, süreçte hâkimin yeri bir anlamda avukatlar aracılığıyla doldurulmaktadır. Boşanma sürecine her iki tarafın avukatlarının da katılımı zorunludur (Code Civil m. 229-1). Hal böyle olunca aslında mahkeme dışı boşanma kurumunun tarafları avukatlık masraflarından kurtardığı düşüncesi dayanaksız kalmaktadır ${ }^{80}$. Ancak avukatların katılımı sözleşmesel boşanma sürecinin daha hakkaniyetli bir şekilde yürütülebilmesi, her iki tarafın menfaatlerinin korunması ve menfaat çatışmalarının önlenebilmesi adına önemlidir ${ }^{81}$. Son aşamada boşanma anlaşmasının noter tarafından tescil edilmesi ile de bir anlamda sürece resmiyet kazandırılmaktadır ${ }^{82}$. Tarafların ergin olmayan çocuklarının bulunması mahkeme dışında gerçekleștirilen bu boşanma usulünün uygulanmasına engel teşkil etmese de ebeveynlerin boşanma süreci ve mahkemede dinlenilme hakları olduğu konusunda çocuklarını bilgilendirmeleri

75 Ryznar, Margaret/Devaux, Angélique (2018) "Voilà! Taking the Judge Out of Divorce", Seattle University Law Review, V:42, I:1, s. 164.

76 Moracchini-Zeidenberg Stéphanie (2018) "La contractualisation de la séparation et de ses conséquences en droit français", Les Cahiers de Droit, V:59, I:4, s. 1116; Ferrand, s. 171; Özcan, s. 648.

77 Bu yönde bkz. Guinchard, Serge (ed) (2008) L'ambition raisonnee d'une justice apaisee, rapport de la Commission sur la Repartition des contentieux remis au Garde des Sceaux, Paris, La documentation française, $<$ https://www.ladocumentationfrancaise.fr/var/storage/rapports-publics/084000392.pdf> s.e.t. 06.10.2019, s. 87 vd.. Bu yöndeki diğer değişiklik önerileri için bkz. Ferrand, s. 167-169.

78 Loi n ${ }^{\circ}$ 2016-1547 du 18 novembre 2016 de modernisation de la justice du XXIe siècle (1), Journal Officiel de La République Française n 0269, 19 novembre 2016.

79 Ryznar/Devaux, s. 165.

80 Ferrand, s. 178; Özcan, s. 653-654.

81 Ryznar/Devaux, s. 166.

82 Özcan, s. 648. 
gerekmektedir ${ }^{83}$. Çocukların mahkemede dinlenmeleri yönünde talepleri olursa artık bu boşanma usulüne başvurulamayacak, boşanma yalnızca hâkim kararıyla gerçekleştirilebilecektir (Code Civil m. 229-2). Aynı şekilde eşlerden birinin koruma altında olması (vesayet altında bulunması veya kendisine kayyım atanmış olması gibi) halinde de boşanmanın mahkeme önünde gerçekleştirilmesi gerekir (Code Civil m. 229-2) ${ }^{84}$.

Yukarıda görüldügü üzere her ne kadar farklı ülke hukuklarında farklı şekilde uygulamalara ve düzenlemelere tabi olsa da mahkeme dışı boşanma kurumu, boşanma sebeplerinden anlaşmalı boşanma için uygulanan bir usul olup titizlikle düzenlendiğinde fayda sağlayacak niteliktedir. Farklı hukuk sistemlerinde bu denli yer tutan ve uygulamasının da artacağ düşünülen bu kurum karşısında Türk hukukunda zaten yer alan anlaşmalı boşanma düzenlemelerini incelemek ve bu aşamada hâkimin rolü üzerinden bir değerlendirme yapmak yerinde olacaktır.

\section{TÜRK HUKUKUNDA DURUM}

\section{A. BOŞANMAYA İLİ̧KKIN DÜZENLEMELER}

\section{Boşanma Konusunda Mahkemenin Tek Yetkili Makam Oluşu}

Yürürlükteki Medeni Kanunumuz uyarınca boşanma, eşlerin sağ olması ihtimalinde kanunda yer alan sebeplere dayanarak eşlerden birinin açacağ dava sonucunda evlilik birliğine hâkimin vereceği kararla son verilmesi şeklinde tanımlanabilir. Tanımdan anlaşılacağı üzere Türk hukukunda kanunda belirtilen sebeplerin varlığı halinde ve yalnızca hâkimin vereceği kararla boşanma kabul edilmektedir ${ }^{85}$. Diğer bir ifadeyle geçerli bir evlilik birliğinin sona erdirilme şekillerinden biri olarak sadece mahkemede boşanma kabul edilmiş olup, bu konuda bir istisna getirilmemiştir.

\footnotetext{
Ryznar/Devaux, s. 167-168.

84 Fransız hukukunda mahkeme dışı boşanma kurumuna yöneltilen eleştiriler konusunda bkz. Ferrand, s. 178 vd.; Moracchini-Zeidenberg, s. 1127 vd.; Özcan, s. 653 vd.

85 Saymen, s. 144; Velidedeoğlu, s. 167; Köprülü/Kaneti, s. 150; Gürsoy, Kemal Tahir (1977) "Eşlerin Anlaşması Suretiyle Boşanma”, Ankara Hukuk Fakültesi 50. Yıl Armağanı, C:2, Boşanma Hukuku Haftası, Ankara, Sevinç Matbaası, s. 157 (borçlar hukukuna tabi olmayan bir sözleşme olarak boşanma anlaşmasının hâkim kontrolüne tabi olması); Oğuzman, Kemal/Dural, Mustafa (1998) Aile Hukuku, 2. Baskı, İstanbul, Filiz Kitabevi, s. 112; Zevkliler, Aydın/Acabey, M. Beşir/Gökyayla, K. Emre (2000) Zevkliler Medeni Hukuk, 6. Baskı, Ankara, Seçkin Yayıncılık, s. 879; Uyanık Çavuşoğlu, s. 25-27; Ekşi, s. 77; Gençcan, Ömer Ŭgur (2015) Boşanma Tazminat ve Nafaka Hukuku, 3. Baskı, Ankara, Yetkin Yayıncılık, s. 99, 113114; Nomer, s. 260; Dural, Mustafa/Öğüz, Tufan/Gümüș, Mustafa Alper (2018) Türk Özel Hukuku, Aile Hukuku, C:3, İstanbul, Filiz Kitabevi, para. 558; Kılıçoğlu, Ahmet M. (2019), Aile Hukuku, 4. Baskı, Ankara, Turhan Kitabevi, s. 3; Akıntürk/Ateş, s. 235.
} 


\section{Boşanma Sebepleri}

\section{a. Genel Olarak}

Hukukumuzda boşanma sebepleri özel (bir olgunun gerçekleşmesine dayalı) ve genel sebeplere dayalı boşanma olmak üzere ikiye ayrılmaktadır. 4721 sayılı Türk Medeni Kanunu (“TMK”) m. 161-165 hükümlerinde boşanmanın özel sebepleri zina; hayata kast, pek kötü muamele ya da onur kırıcı davranış; küçük düşürücü suç işleme ve haysiyetsiz hayat sürme; terk ve akıl hastalığ olarak düzenlenmişken; TMK m. 166 hükmünde boşanmanın genel sebepleri öngörülmüştür. TMK m. 166 uyarınca, üç tür genel boşanma sebebi bulunmaktadır. Bunlardan ilki, evlilik birliğinin temelinden sarsılması (TMK $\mathrm{m}$. 166/I,II); ikincisi, eşlerin birlikte dava açmaları ya da birinin açtığı davayı diğerinin kabul etmesi (anlaşmalı boşanma, TMK m. 166/III) ve son olarak boşanma sebeplerinden herhangi biriyle açılmış bulunan davanın reddine kadar verilmesinden sonra eşlerin ortak hayatı yeniden kuramamış olmalarıdır (TMK m. 166/IV).

\section{b. Hukukumuzda Eşlerin Boşanma Konusundaki İrade Serbestisi: Anlaşmalı Boşanma}

Yukarıda farklı ülke hukuklarında yer alan düzenlemelerden görüldüğü üzere mahkeme dişı boşanma kurumu da eşlerin boşanma ve boşanmanın sonuçları konusunda anlaşmalarına dayanmaktadır. Türk Medeni Kanunu'nda yer almayan bu kurumu anlaşmalı boşanmanın hukukumuzda kabul edilmesinin altında yatan nedenler doğrultusunda ve toplumun evlilik birliğine atfettiği değeri (akdi bir birliktelik veya dini temele dayalı mukaddes bir birliktelik gibi) göz önüne alarak ${ }^{86}$ ele almak yerinde olur.

Önceleri boşanmanın kamu düzeniyle ilgili olduğ ${ }^{87}$, kadının kiminle ve hangi koşullarla evleneceğine ailenin karar verdiği ve anlaşmalı boşanma imkânının kanunda tanınması halinde yine ailenin bu kez menfaat uğruna (örneğin, kadını başlık parası karşıllğııda bu kez başka bir adamla evlendirmek için) kadın üzerinde boşanması için baskı kurabileceği ${ }^{88}$ gerekçeleri ileri sürülerek eşlerin anlaşmalı olarak boşanmasının mümkün olmadığı savunulmuş ve bu sebeple anlaşmalı boşanma reddedilmiştir. Bu dönemde anlaşmalı boşan-

\footnotetext{
86 Gürsoy, s. 127.

87 Türk Medeni Kanunu Ön Tasarısı ve Gerekçesi, Ankara 1971, s. 112-113; Saymen, s. 124-125.

88 Şener, s. 234-235. Ayrıca Feyzioğlu, eserin yayımlandığı tarihte toplumun yapısı itibariyle Türk kadınının anlaşmalı boşanma imkânını eşit koşullar altında kullanamaması tehlikesine dikkat çekmiştir. Bkz. Feyzioğlu, Feyzi Necmeddin (1979) Aile Hukuku, 2. Bask1, İstanbul, Fakülteler Matbaası, s. 364-365.
} 
ma imkânının getirilmesi yönünde görüşlere ise nadiren rastlanmaktadır. Örneğin öğretide GÜRSOY, eşlerin kökünden sarsılmış, haysiyetini kaybetmiş evliliğe devam etmeye zorlanamayacağını savunmuştur ${ }^{89}$.

Çokça tartışma ve aradan geçen uzun zaman sonrasında kanun koyucu, değişen dünya düzeni, ihtiyaçlar ve bunlar içerisinde özellikle de kadının sosyal hayatta ve evlilik kurumundaki yerinin değişmesi gibi gelişmeleri takiben 1926 tarihli ve 743 sayılı Türk Kanunu Medenisi’ne 4.5.1988 tarihinde ve 3444 sayılı Kanunla getirilmiş, değişikliklerle (ETMK m. 134/III'e eklenen yeni fikra; Art. 111, 112 ZGB) eşlerin anlaşarak evlilik birliğini sona erdirmelerine izin vermiştir. Boşanma sistemimize mülga Kanun zamanında girmiş anlaşmalı boşanma kurumuna yürürlükteki 4721 sayılı Türk Medeni Kanunu’nda da yer verilmiştir.

Genel olarak anlaşmalı boşanma, eşlerin özgür iradeleriyle anlaşarak aralarındaki evlilik ilişkisini sonlandırmalarıdır ${ }^{90}$. Anlaşmalı boşanma kurumuyla eşlere basit ve önceden belirledikleri koşullarda, hızlı bir şekilde evlilik birliğini sona erdirme imkânı tanınmaktadır ${ }^{91}$. Ancak kanun koyucunun yine de eşlere evlilik birliğini sona erdirme bakımından sonsuz bir serbesti vermediği görülmektedir. Aksine evlilik birliğinin sona erdirilmesi konusunda TMK m. 166/III'te düzenlenen anlaşmalı boşanmada eşlerin sınırlı bir irade serbestisine sahip oldukları görülmektedir ${ }^{92}$.

Anlaşmalı boşanmanın söz konusu olabilmesi için evliliğin başlangıcından itibaren ${ }^{93}$ en az bir yıl geçmiş olması ve eşlerin boşanmak üzere birlikte başvurmaları ya da bir eşin diğerinin davasını kabul etmesi gerekmektedir (TMK m. 166/III). Anlaşmalı boşanma imkânı, evlilik birliğinin temelinden

89 Ayrıntılı bilgi ve eleştiriler için bkz. Gürsoy, s. 151-163.

90 Gürsoy, s. 127; Seçer, Öz (2009) "İsviçre ve Türk Hukuklarında Anlaşmalı Boşanma ve Fiili Ayrılık Sebebiyle Boşanma”, Bahçeşehir Üniversitesi Hukuk Fakültesi Kazancı Hakemli Hukuk Dergisi, S:63-64, s. 40; Seçer, Öz (2016) "Anlaşmalı Boşanmada Eşlerin Yaptıkları Anlaşma”, İnönü Üniversitesi Hukuk Fakültesi Dergisi, C:7, S:2, s. 260.

Evlenmenin gerçekleşmesinde kabul edilen "eșlerin iradesine tabi olma" olgusunun evlenme gerçekleștikten sonra boşanma konusunda kabul edilemeyeceği yönünde bkz. Velidedeoğlu, s. 167; Köprülü/Kaneti, s. 152153. "Irade ilkesi" hakkında bkz. Ceylan, s. 321.

91 Özdemir (2003), s. 107; Öztan, s. 692.

92 Zevkliler/Acabey/Gökyayla, s. 881-882; Özdemir (2003), s. 107; Öztan, s. 692. Eşlere boşanma konusunda sınırsız yetki verilmemesinde kuşkusuz ailenin toplumun temeli olarak kabul edilmesi ve bu sebeple evliliklerin gelişigüzel sebeplerle sona erdirilmemesi gerektiği düşüncesinin kabulü de etkili olmuştur. Boşanma davası sonunda verilecek evlilik birliğinin sonlandırılmasına ilişkin karar göz önüne alındığında boşanma davasının gerek eşler gerekse çocuklar açısından önemli hukuki sonuçlar doğuracağı açıktır. Aynı yönde bkz. Zevkliler/Acabey/Gökyayla, s. 878; Kılıçoğlu (2019), s. 2. Aile kurumunu korumak uğruna eşlerin özgürlügünün sınırlanması konusunda eşlerin kendi menfaatleri ile çocuğun menfaati arasında dengeli olacak şekilde, yetkilerini aşırı ölçüde daraltmayan bir sonuca varılması gerektiği yönünde bkz. Ceylan, Ebru (2018) "İsviçre, Fransa, Belçika, İspanya ve İtalya Hukukundaki Boşanma Sebeplerinin Türk Hukukuyla Mukayesesi”, Uyuşmazlık Mahkemesi Dergisi, C:6, S:12, s. 331.

93 Öztan, s. 694; Yılmaz Bilgin, Esra Pınar (2016) Türk Hukukunda Anlaşmalı Boşanma, İstanbul, On İki Levha Yayıncılık, s. 42; Seçer (2016), s. 261; Akıntürk/Ateş, s. 270; Kılıçoğlu (2019), s. 111. 
sarsılmasına ve bu durumun ortak hayatın sürdürülmesinin beklenememesine dayanmaktadır ${ }^{94}$. Bu sebeple kanun koyucu, anlaşmalı boşanma imkânını ayrı bir hüküm ile düzenleme yoluna gitmemiş, bu boşanma türüne evlilik birliğinin temelinden sarsılmasını düzenleyen TMK m. 166 hükmü içerisinde yer vermiştir ${ }^{95}$.

Bu boşanma usulünde hâkimin boşanmaya karar vermeden önce tarafları bizzat dinlemesi ve onların iradelerini serbestçe açıladıklarına kanaat getirmesi gerekir ${ }^{96}$. Diğer bir ifadeyle anlaşmalı boşanmada hâkim tarafları bizzat dinlemekten imtina edemez (boşanmanın şartı olarak tarafların dinlenmesi $)^{97}$. Hâkimin boşanma anlaşmasını denetleyip onaylaması ise tarafların ve çocukların menfaatinin korunması düşüncesine dayanmaktadır (TMK $\mathrm{m}$. 166/III c. 3) ${ }^{98}$. Bu bağlamda hâkimin boşanmanın mali sonuçları (maddi, manevi tazminat talepleri, yoksulluk nafakası) ile çocukların durumu (velayet, çocukla ilişki kurulması, iştirak nafakası) hususunda tarafların yapmış oldukları anlaşmayı uygun bulması gerekir ${ }^{99}$. Hâkimin burada yapacağı denetim,

94 Zevkliler/Acabey/Gökyayla, s. 879; Öztan, s. 693; Fankhauser, Roland (2017) Schwenzer, Ingeborg/Fankhauser, Roland (Hrsg.), Fam Kommentar, Scheidung, Band I: ZGB / Band II: Anhänge, 3. Aufl., Bern, Stämpfli Verlag, Art. 111, N. 2; Dural/Öğüz/Gümüsş, para. 647; Kılıçoğlu (2019), s. 111.

95 Zevkliler/Acabey/Gökyayla, s. 879; Akıntürk/Ateş, s. 269.

96 Yargitay 2. Hukuk Dairesi, E: 1992/1456, K: 1992/1636,T: 13.2.1992; Yargttay, 2. Hukuk Dairesi, E: 2004/428, K: 2004/1064, T: 28.1.2004; Yargitay, 2. Hukuk Dairesi, E: 2005/3734, K: 2005/5622, T: 7.4.2005; Oğuzman/Dural, s. 127, 129; Zevkliler/Acabey/Gökyayla, s. 904; Öztan, s. 692; Seçer (2016), s. 261 vd.; Akıntürk/Ateş, s. 270-271; Kılıçoğlu (2019), s. 113. Burada bahsi geçen anlaşmalı boşanma davasında eşlerin anlaşma iradelerini hâkim önünde açıklamalarıdır, yoksa eşlerin bizzat kendileri tarafından boşanma davasının açılması gerekmez. Eşler boşanma davasını vekilleri aracılığıyla açabilirler. Akıntürk/Ateş, s. 271; Kılıçoğlu (2019), s. 113.

97 Yargitay 2. Hukuk Dairesi, E: 1989/10658, K: 1990/2000, T: 19.2.1990; Yargitay 2. Hukuk Dairesi, E: 2004/428, K: 2004/1064, T: 28.1.2004; Yargitay, 2. Hukuk Dairesi, E: 2005/3734, K: 2005/5622, T: 7.4.2005; Yargitay 2. Hukuk Dairesi, E: 2006/12012, K: 2006/18557, T: 28.12.2006; Oğuzman/Dural, s. 129; Ercan, İbrahim (2014) "Boşanma Davalarında Geçerli Olan Yargılama İlkeleri”, Süleyman Demirel Üniversitesi Hukuk Fakültesi Dergisi, C:4, S:2, s. 266; Öztan, s. 693-694; Seçer (2016), s. 262, 263, 266; Akıntürk/Ateș, s. 271. İsviçre'de bu yönde bkz. Rumo-Jungo, Alexandra (2016) Breitschmid, Peter/RumoJungo, Alexandra (Hrsg.), CHK - Handkommentar zum Schweizer Privatrecht, Personen- und Familienrecht - Partnerschaftsgesetz, Art. 1-456 ZGB - PartG, 3. Aufl., Zürich, Schulthess Verlag, Art. 111 N. 17-18; eşin ağır şekilde engelli olması, yurt dışında hapiste olması gibi önemli sebeplerle ve istisnai hallerde eşin dinlenilmesinden vazgeçilebileceği hakkında bkz. Fankhauser, Art. 111, N. 16. Davalı ve davacı eşin hâkim tarafindan aynı anda ve bizzat dinlenmesi gerektiği; yalnızca eşlerin vekillerinin dinlenilmesi ile eşlerin serbest iradelerinin tespit edilemeyeceği yönünde bkz. Yargitay 2. Hukuk Dairesi, 13.02.1992, 1456-1636; Gençcan, s. 692-693.

98 Tekinay, Selahattin Sulhi (1982) Türk Aile Hukuku, 4. Baskı, İstanbul, Fakülteler Matbaası, s. 293, 297; Gürzumar, Aydanur (1991) Die rolle des Richters im Ehescheidungsprozess in der Schweiz und in der Türkei, İzmir, Bizim Büro Basımevi, s. 173.

99 Tekinay, s. 296; Ercan, s. 256-257; Öztan, s. 694 vd.; boşanmanın mali sonuçları üzerinde anlaşmaya maddi, manevi tazminat ve yoksulluk, iştirak nafakasının dahil olacağı hakkında bkz. Yargitay Hukuk Genel Kurulu, E: 2009/2-158, K: 2009/217, T: 27.5.2009; Yargitay Hukuk Genel Kurulu, E: 2010/2-96, K: 2010/106, T: 24.2.2010; Yargitay 8. Hukuk Dairesi, E: 2010/4983, K: 2011/2095, T: 12.4.2011; Özdemir (2003), s. 159; Seçer (2009), s. 54; Kılıçoğlu (2019), s. 127 vd. Boşanma davasında boșanma protokolünün hâkim tarafindan denetimi ve onayı hakkında ayrıntılı bilgi için bkz. Gürzumar, s. 173 vd. Eşler arasındaki 
boşanma anlaşmasının kurulması ve içeriğine ilişkin olup eşlerin boşanma ve sonuçları hakkında serbest iradeleriyle karar verip vermediklerinin tespitinden ${ }^{100}$; eşlerin mahkemeye sundukları boşanma anlaşmasının kendilerinin ve çocuklarının menfaatine uygunluğunun incelenmesinden ve anlaşmanın ahlaka ve adaba aykırılık, gabin veya irade sakatlığı yönünden incelenmesinden ibarettir ${ }^{101}$. Ayrıca hâkimin denetimi ile taraflardan birinin sömürülmesi ve hakkaniyete aykırı sonuçlar meydana gelmesi önlenmek istenmektedir ${ }^{102}$. Hâkim yapacağı değerlendirme sonucunda olumsuz kanaate varırsa boşanma anlaşmasını hangi gerekçeyle eşlerin ya da çocuğun menfaatine aykırı bulduğunu ve anlaşmanın ne şekilde yeniden düzenlenmesi gerektiğini eşlere açıklamalıdır ${ }^{103}$. Buna karşılık anlaşmalı boşanma davasında hâkimin eşlerin evlilik birliğinin gerçekten sarsılıp sarsılmadığına ilişkin bir tespitte bulunma yükümlülüğü (TMK m. 166/I, II) bulunmamaktadır ${ }^{104}$. Eşlerin boşanma konusundaki iradelerini serbestçe açıladıklarına kanaat getiren hâkim, maddi vakıalar evlilik birliğinin sarsıldığını tam olarak ortaya koyamasa da boşanma-

anlaşmanın içeriği eşler arasındaki mali konular ve çocukların durumu ile sınırlı değildir. Bu konular boşanma anlaşmasının olmazsa olmaz konularıdır. Dolayısıyla eşlerin sözleşme serbestisi kapsamında başkaca konularda, örneğin aile konutuna ilişkin anlaşma yapabilmesi mümkündür. Bkz. Özdemir (2003), s. 169; Seçer (2016), s. 273 vd. Öğretide mal rejiminin tasfiyesinin boşanmanın fer'i sonuçları arasında görülmemektedir Kılıçoğlu, Ahmet M. (2002), Edinilmiş Mallara Katılma Rejimi, 2. Baskı, Ankara, Eda Matbaası, s. 59-60; Özdemir (2003), s. 168; Zeytin, Zafer (2017) Edinilmiş Mallara Katılma Rejimi ve Tasfiyesi, 3. Baskı, Ankara, Seçkin Yayıncılık, s. 326, dn. 826. Karş. Tekinay, s. 296; Burcuoğlu, Haluk (2004) “4721 Sayılı Yeni Medeni Kanunun Boşanma Düzenlemesinin Eleştirisi ve Uygulamada Karşılaşılabilecek Sorunlar", Antalya Barosu Dergisi, S:5/51, s. 68; Sarı, Suat (2007) Evlilik Birliğinde Yasal Mal Rejimi Olarak Edinilmiş Mallara Katılma Rejimi, İstanbul, Beşir Kitabevi, s. 16, dn. 21, s. 105-106.

Yargıtay da anlaşmalı boşanma usulünde mal rejiminin tasfiyesinin kararlaştırılmasının zorunlu olmadığı, ancak buna engel bir durumun olmadığı görüşündedir. Yargıtay 8. Hukuk Dairesi, E: 2010/4983, K: 2011/2095, T: 12.4.2011; Yargitay, 2. Hukuk Dairesi, E: 2014/11715, K: 2014/25146, T: 9.12.2014. Anlaşmalı boşanma çerçevesinde mal rejiminin tasfiyesine ilişkin anlaşmalar hakkında ayrıntılı bilgi için bkz. Öncü, Özge (2017) "Eşlerin "Anlaşmalı Boşanma" Çerçevesinde Mal Rejiminin Tasfiyesine Yönelik Olarak Yaptıkları Anlaşmalar ve Bu Anlaşmaların Uygulamada Doğurduğu Sorunlar”, Dokuz Eylül Üniversitesi Hukuk Fakültesi Dergisi, Prof. Dr. Şeref ERTAŞ’a Armağan, C:19, Özel Sayı, s. 793-835.

100 Art. 111 Abs. 2 ZGB'de açıkça bu husus ifade edilmiştir. Ayrıca bkz. Reusser, Ruth (1999) "Die Scheidungsgründe und die Ehetrennung": Hausheer, Heinz (ed), Vom alten zum neuen Scheidungsrecht, Bern, Stämpfi Verlag AG, s. 21-22, N. 1.37; Rumo-Jungo, Art. 111, N. 15-16; Fankhauser, Art. 111, N. 12, 18.

101 Gürzumar, s. 173, 181-182; Özdemir (2003), s. 171-172; Öztan, s. 696; Seçer (2016), s. 277; Jungo, Alexandra CHK - Handkommentar zum Schweizer Privatrecht, Personen- und Familienrecht - Partnerschaftsgesetz, Art. 1-456 ZGB - PartG, Zürich 2016, Art. 111 ZGB, N. 15.

102 İsviçre hukukundaki hâkim görüş hakkında bkz. Grassinger, Gülçin Elçin (1997) "Boşanma Davasında Eşlerin Boşanmanın Tali Sonuçlarına İlişkin Konularda Anlaşma Yapmaları ve Konu İle İlgili İsviçre Federal Mahkemesi Kararı", İstanbul Üniversitesi Hukuk Fakültesi Mecmuası Prof. Dr. Türkan Rado’ya Armağan Sayıs1, C:LV, S:3, s. 238; BGE 121 III 393.

103 Özdemir (2003), s. 172.

104 Sutter, Thomas/Freiburghaus Dieter (1999) Kommentar zum neuen Scheidungsrecht, Zürich, Schulthess, Vorb. zu Art. 111-118, N. 10; Reusser, s. 22, N. 1.37; Özdemir (2003), s. 147; Öztan, s. 699; Fankhauser, Art. 111, N. 15. 
ya karar vermek zorundadır ${ }^{105}$. Daha açık bir ifadeyle hâkim, hükümde sayılan şartların gerçekleşmesi halinde boşanmaya karar vermekten kaçınamayacaktır. Bu şartların kamu düzeninden kabul edildiği de göz ardı edilmemelidir ${ }^{106}$.

Üzerinde ayrıca durulması gereken konulardan biri de çocuğun menfaatinin korunması kapsamında çocuğun hâkim tarafından dinlenilmesi imkânıdır. Boşanma sürecinin mahkeme önünde devam ettirilmesi düşüncesinin altında yatan nedenlerden biri de yukarıda ifade edildiği üzere çocuğun taleplerinin de boşanma sürecinde ve boşanma sonrasında anne ve/veya baba ile kişisel ilişkinin düzenlemesi aşamasında dikkate alınabilecek olmasıdır. Türk Medeni Kanunu'nda hâkimin taraf menfaatleri ve çocukların çıkarlarının korunup korunmadığı hakkında yapacağı incelemede çocukların dinlenmesine ilişkin bir hüküm bulunmamakla birlikte ${ }^{107}$ tarafı bulunduğumuz milletlerarası anlaşmalarda bu durum hüküm altına alınmıştır. Bu yönde Çocuk Hakları Sözleşmesi m. $12^{108}$ ve Çocuk Haklarının Kullanılmasına İlişkin Avrupa Sözleşmesi m. 3 ve m. $6^{\prime} \mathrm{da}^{109}$ düzenlemeler yer almaktadır. Buna göre, çocuğun taraf devletlerin maddi hukukları bakımından ayırt etme gücüne sahip olduğu durumlarda, adli merciler önünde kendisini ilgilendiren davalarda, kendisi lehine ilgili tüm bilgileri almak; kendisine danışılmasını talep etmek ve görüşlerini ifade etmek; görüşlerinin uygulanması ve her tür kararın olası sonuçları bakımından bilgilendirilme hakkı bulunmaktadır. Yargıtay'ın farklı kararlarında da söz konusu sözleşme maddelerine gönderme yapılarak, çocuğa ilk derece mahkemesince görüşünü ifade etme olanağı tanınmaması bozma sebebi olarak kabul edilmiştir ${ }^{110}$. Kanaatimizce bilhassa velayet sorununun çözümünde fayda sağlayan çocuğun dinlenilmesine ilişkin yapılacak düzenle-

105 Özdemir (2003), s. 147; Dural/Öğüz/Gümüș, para. 633; Akıntürk/Ateș, s. 269-272.

106 Yargitay 2. Hukuk Dairesi, , E: 1989/10658, K: 1990/2000, T: 19.2.1990; Oğuzman/Dural, s. 129; Seçer (2009), s. 51; Gençcan, s. 693.

107 Çocukların durumuna ilişkin anlaşmanın uygunluğunu denetleme bakımından da çocuğun dinlenmesi ile ilgili hükümlerin konulmasının uygun olacağı yönünde bkz. Özdemir, Saibe (2009) "Boşanma Davalarında Çocuklara İlişkin Kararlar Bakımından Çocuğun Dinlenilme Hakkı”, Prof.Dr. Hüseyin Hatemi’ye Armağan, C:2, İstanbul, Vedat Kitapçılık, s. 1219-1242; Seçer (2009), s. 50; Oktay Özdemir, Saibe (2015) “Türk Hukukunda Boşanma Sisteminde Revizyon İhtiyacı", Milletlerarası Hukuk ve Milletlerarası Özel Hukuk Bülteni, C:35, S:1, s. 38.

108 Sözleşme metni için bkz. <https://www.ohchr.org/en/professionalinterest/pages/crc.aspx> s.e.t. 06.10.2019. Türkiye Sözleşme’yi 14 Eylül 1990 yılında imzalamış ve 4058 sayılı onay kanunu 11 Aralık 1994 gün ve 22138 sayılı Resmi Gazete'de yayınlanmıştır.

109 Sözleşme metni için bkz. <https://www.coe.int/en/web/conventions/full-list///conventions/rms/ 090000168007cdaf’> s.e.t. 06.10.2019. Türkiye Sözleşme'yi 9 Haziran 1999 tarihinde imzalamış ve 4620 say1lı onay kanunu 1 Şubat 2001 gün ve 24305 sayılı Resmi Gazete'de yayınlanmıştır.

110 Yargitay 2. Hukuk Dairesi, E: 2014/18010, K: 2015/2708, T: 25.2.2015; benzer yönde bkz. Yargıtay 2. Hukuk Dairesi, E: 2009/3600, K: 2010/5346, T: 22.3.2010; Yargitay 2. Hukuk Dairesi, E: 2015/12193, K: 2016/2789, T: 17.2.2016. 
me ${ }^{111}$ boşanma sonrası yaşanan travmaların azaltılmasını ve hâkimin özellikle velayet konusundaki anlaşmaları kolaylıkla onaylayabilmesini sağlayacaktır. Çalışma konumuzla bağlantılı olarak tespitte bulunmak gerekirse, bazı ülke hukuklarında olduğu gibi bizim hukukumuzda da anlaşma temeline dayalı mahkeme dışı boşanma usulünün işletilebilmesini eşlerin çocuklarının olmaması şartına bağlamak yerinde olabilir. Böylece eşlerin ortak çocuklarına ilişkin talepleri tarafsız hâkimler tarafından denetlenebilecek ve çocuğun menfaati daha iyi korunabilecektir.

\section{c. Hukukumuzda Mahkeme Dışı Boşanma Düşünülebilir Mi?}

Görüldüğü üzere yukarıda bazı örnekleri verilen ülke hukuklarında kabul edilmiş olan mahkeme dişı boşanma kurumuna temel oluşturan anlaşmalı boşanma, TMK m. 166/III hükmünde de düzenlenmiştir. 2016 yılına ait istatistik sonuçlarına göre ülkemizde açılan 212.000 'den fazla boşanma davasının 94.000'den fazlası anlaşmalı olarak açılmıştır ${ }^{112}$. Buradan anlaşılacağı üzere boşanma davalarının önemli bir kısmında eşler anlaşmalı boşanma talebinde bulunmaktadır. $\mathrm{Bu}$ yönüyle mahkeme dışı boşanma kurumunun hukukumuz açısından uygulamada fayda sağlayabileceği kanaatindeyiz. Ancak dikkat etmek gerekir ki TMK m. 166/III hükmü uyarınca anlaşmalı boşanmada dahi hâkim denetiminden vazgeçilmemiştir. Anlaşmalı boşanma hukukumuzda, belirli şartların varlığına ve hâkimin vereceği karara bağlıdır ${ }^{113}$. Dolayısıyla salt eşlerin karşılıklı anlaşmalarına dayalı ${ }^{114}$ boşanma serbestisinden bahsedilmesi mümkün değildir ${ }^{115}$.

111 Dikkat çekmek gerekir ki mehaz İsviçre Medeni Kanunu'nda çocuğun dinlenilmesine ilişkin ZGB m. 144 f. 2 hükmü kaldırılmıştır. Bunun yerine çocuğun mahkemede dinlenilmesi İsviçre Hukuk Muhakemeleri Kanunu (Zivilprozessordnung, ZPO) m. 298 uyarınca gerçekleşmektedir. Bu yönde yapılan değişikliğin ardından çocuğun dinlenilme hakkı ve bu hakkın sağladığı fayda İsviçre'de tartışılmaktadır. İsviçre'de yalnızca boşanma davalarının yüzde onunda hâkimleri çocukları dinlediğini ifade eden UNICEF Çocuk Yardım Örgütü üyesi Katrin Piazza, hâkimlerin bilgisizlik veya emin olamama ya da uygulamadaki sebeplerden çocukların dinlenilmediğini ekliyor,

$<$ https://www.familienleben.ch/kind/alleinerziehend/anhoerung-von-kindern-bei-scheidungen-2881> s.e.t. 06.10.2019. Çocuğun dinlenmesi usulü, İsviçre'de kantondan kantona farklılık göstermekle birlikte kural olarak çocuğun davet edilerek ve uzman bir avukat veya sosyal hizmet uzmanı ile birlikte dinlenmesi şeklinde gerçekleşmekte; dinlenilme esnasında çocuğa boşanma sonrası kiminle kalmak istediği veya annesi ya da babasıyla ne kadar zaman geçirmek istediği sorulmaktadır. Çocuğun dinlenmesi hakkında bkz. Sutter/Freiburghaus, Art. 144, N. 15; Fankhauser, Art. 111, N. 17.

112 Bu yönde bkz. <https://www.posta.com.tr/turkiye-nin-bosanma-istatistikleri-2016-haber-fotograf-13291563 > s.e.t. 06.10.2019.

113 Boşanma anlaşmasının geçerliliğinin hâkimin onayına bağlı olduğu hakkında bkz. Gürzumar, s. 173.

114 Boşanma konusunda bireyci görüş için bkz. Öztan, s. 637; Gençcan, s. 100-106.

115 Burada kanun koyucunun evlilik birliğinin sonlandırılması konusundaki bu sık tutumunun evlilik birliğinin kurulması hakkında da geçerli olup olmadığı sorusu akla gelmektedir. Her ne kadar konumuzu boşanma kurumu oluştursa da tutum farklılığının görülmesi açısından bu konuya da değinmekte yarar vardır. Boşanmanın 
Evlilik kurumunun anlamı ve bu kurumun sona erme yollarından biri olarak boşanmanın kamu düzenini ilgilendiren yönü dikkate alındığında ${ }^{116}$, evliliğin herhangi bir borç doğuran sözleşme gibi hiçbir şarta bağlı olmaksızın sona ermesine elbette çekinceyle yaklaşmak gerekir ${ }^{117}$. Zira hızlı bir şekilde boşanmanın doğuracağı sonuçlar birden fazla faktöre bağlıdır. Mahkeme dışı boşanma eşlerin kültür, eğitim seviyelerine, mali ve psikolojik durumlarına vb. değişkenlere bağlı olarak olumlu veya olumsuz sonuç doğurabilir. Bu açıklamalar çerçevesinde her ne kadar az bir ihtimal gibi görünse de özellikle şiddete maruz kalan veya maddi açıdan hakkını savunamayacak olan eşler bakımından mahkeme denetiminden geçmeyen boşanma anlaşmalarının hukukumuzda kabul edilmemesi düşüncesindeyiz. Bu tip durumlarda mahkeme denetiminden geçmeyen boşanmalar eşler arasındaki menfaat dengesinin bozulması ve eşlerden birinin diğeri üzerinde baskı uygulayarak aşırı derece orantısız anlaşmaların yapılması tehlikesini her daim barındırmaktadır ${ }^{118}$. Ülkemizin sosyal gerçekleri gözlemlendiğinde bilhassa kadın eşlerin bu tip vakıalarda boşanma ve sonuçlarına yönelik iradelerini hâkim önünde daha rahat ifade edebilmeleri sıkça karşılaşılan bir durumdur. Dolayısıyla bu tip

idari makamlar önünde gerçekleşmesinin mümkün olup olmadığı konusunda evlenmenin idari makamlar önünde, evlendirme memurunun katılımı olmaksızın gerçekleşmesi hakkında hukukumuzdaki düzenlemelerden bazıları ve bunlara yönelik öğretideki görüşler dikkat çekicidir.

1991- 1996 tarihleri arasında yürürlükte olan Bir Evlenme Akdine Dayanmayan Birleşmelerin Evlilik ve Evlilik Dışında Doğan Çocukların Düzgün Nesepli Olarak Tesciline İlişkin Kanun'a ilişkin olarak öğretide "nikahsız birlikte yaşamaların idari yolla geçerli bir evlenmeye çevrilmesi, kanuna ve kamu düzenine aykarı olduğu gibi, son derece sakncalı" olduğu ileri sürülmüştür. Dural/Öğüz/Gümüşs, para. 420 vd. Resmi nikah olmaksızın birlikte yaşama sonucu dünyaya gelen çocukların durumu geçmişten beri devam eden bir sorundur. Bu soruna dayalı olarak çıkan af kanunları hakkında bkz. Velidedeoğlu, s. 155.

Öte yandan evlenecek eşlerin her ikisinin de rıza göstermesi halinde müftülerin ve müftülük personelinin de nikah memuru sıfatıyla nikah kıyabileceklerine ilişkin 19.10.2017 tarihinde değiştirilen Nüfus Hizmetleri Kanunu m. 22/II hükmünün yeni düzenlemesi üzerinde durulan güncel bir konudur. Nikah kıyma yetkisinin nikah memurları yanında devlet memuru statüsündeki müftü ve müftülük memurlarına verilmesi, "Vatandaşlarımızın evlenme işlemlerini kolaylaştırmak ve daha kolay ve seri bir şekilde hizmet sağlamak amactyla il ve ilçe müftülüklerine evlendirme yetkisi verilmektedir." şeklinde gerekçelendirilmiştir. Bkz. 7039 sayılı Kanun'un genel gerekçesi,

https://mevzuat.tbmm.gov.tr/mevzuat/faces/kanunmaddeleri?pkanunlarno=214270\&pkanunnumarasi $=7039$. Değişikliğin yapıldığı dönemde anılan kanun değişikliğine farkı yönlerden eleştiriler getirilmiş olmakla birlikte çalışma konumuz açısından bu eleştirilere değinilmeyecektir. Bkz. ayrıca Evlendirme Yönetmeliği m. 7/I c. 2 ve $\mathrm{m}$. 8/III. Buradan anlaşılacağı üzere kanun koyucu bazı hallerde evlilik birliğinin kurulmasını hızlandırma yönünde tutum sergilemektedir.

116 Boşanma davalarının kamu hukukuna ilişkin olması hakkında bkz. Yargıtay 2. Hukuk Dairesi, E: 1997/5261, K: 1997/6503, T: 5.6.1997; Özmumcu, Seda (2014) “Türk Hukukunda Yargıtay Kararları Ișığında Re'sen Araştırma İlkesi”, Süleyman Demirel Üniversitesi Hukuk Fakültesi Dergisi, C:4, S:2, s. 161. Kamu düzeni düşüncesiyle Fransız hukukunda kabul edilen mahkeme dışı boşanma kurumunun da eleştirilere maruz kaldığı belirtilmektedir: Özcan, s. 653 .

117 Aynı yönde çekincelerin Fransız hukukunda kabul edilen mahkeme dışı boşanma kurumuna yönelik de söz konusu olduğu hakkında bkz. Özcan, s. 658, dn. 40’ta belirtilen yazarlar. 
olayların söz konusu olduğu durumlar için mahkeme dışı boşanma elbette savunulamaz.

Ancak bu tip durumların söz konusu olmadığı, eşler arasındaki boşanma anlaşmasının menfaat dengeleri gözetilerek hazırlandığı durumlarda mahkeme dışı boşanma kurumunun kabulü düşünülebilir. Dolayısıyla farklı ülke hukuklarındaki düzenlemeler ve uygulamalar ışığında ülke gerçekleri ve hukuk sistemimiz dikkate alınarak koşulları önceden belirlenecek şekilde yasal düzenlemeler yapıldığı sürece mahkeme dışı boşanma kurumunun tamamen reddedilmemesi görüşündeyiz.

\section{SONUÇ}

Her ne kadar hukukumuzda boşanma konusunda hâkimin son sözü söyleyeceği kabul edilse de farklı ülke hukuklarında yaşanan gelişmeler görmezden gelinemez. Çalışmamızın ana konusunu oluşturan mahkeme dış1 boşanma kurumu da boşanma hukuku konusunda ele alınması gereken önemli bir boşanma usulüdür. Kısaca mahkeme dışı boşanma, boşanma konusunda anlaşmaya varan eşlere mahkemeye gitmeden, idari makamlar önünde boşanmayı gerçekleștirilebilme hakkının tanınması olarak ifade edilebilir.

Öğretide mahkeme dışı boşanma kurumunu olumlu ve olumsuz olarak gören iki görüş bulunmaktadır. Olumlu olarak gören görüş uyarınca mahkeme dışı boşanma, zaten boşanma konusunda hemfikir olan ve boşanmanın eşler ve çocuklar bakımından önemli sonuçları hakkında anlaşmış olan eşlerin mahkeme önüne gitmesine gerek kalmaksızın hızlı ve daha az masraflı olacak şekilde boşanabilmesine olanak vermesi açısından fayda sağlayacak niteliktedir. Ayrıca bu boşanma türünde eşlerin ve çocukların boşanma sürecinde ve sonrasında daha az yıpranacakları açıktır. Öte yandan mahkeme dışı boşanma kurumunu olumsuz olarak gören görüş, kamu düzeni düşüncesine ve boşanma sürecinde özellikle eş ve çocukların menfaatlerinin korunması açısından hâkimin rolünün önemine dayanmaktadır.

Mahkeme dışı boşanma kurumu bugün pek çok ülke hukukunda kabul edilmiştir. Bu ülkelerde mahkeme dışı boşanma kurumu ya uzun yıllardır uygulanan bir gelenek olarak ya da boşanma hukukunun adli alandan çıkarılması sürecinin bir parçası olarak ortaya çıkmıştır. Bu ülkelerde mahkeme dışı boşanmanın şartları ve boşanmanın gerçekleştirilebileceği makamlar açısından farklılıklar bulunmaktadır. Örneğin, eşler vali önünde (Norveç), nüfus memurları önünde 
(İtalya), adli hizmet memuru veya noter önünde (İspanya), Aile Hukuku Ajansı "Familieretshuset" tarafindan (Danimarka) ve noter tarafından tutulan sicile tescil yoluyla (Fransa) boşanabilmektedirler. Ancak örnek olarak incelenen tüm ülke hukuklarındaki düzenlemelerin ortak yanı mahkeme dışı boşanmaya anlaşmalı boşanma için izin verilmiş olmasıdır.

Hukukumuzda da anlaşmalı boşanma kabul edilmiş olmasına rağmen ailenin korunması yönündeki genel eğilimin sonucu olarak evlilik birliği üzerinde eşlere tanınacak yetkinin kapsamı kanun koyucu tarafından daraltılmıştır. Anlaşmalı boşanmada dahi eşlerin boşanma yönünde kararlarını mahkeme önünde açıklamaları ve boşanma anlaşmalarının (anlaşma protokolünün) hâkim denetiminden geçmesi bu sonucu doğrulamaktadır. Anlaşmalı boşanma kurumunda üzerinde hassasiyetle durulan konu, eşlerin ve ortak çocuğun menfaatlerinin zedelenmemesi ve adil olmayan sonuçların önüne geçilmesidir. Ayrıca eşlerin boşanma ve boşanmanın mali sonuçları ile çocuklar hakkında anlaşmış olsalar bile bu arzularını bir kez daha hâkim önünde dile getirmelerinin istenmesinin sebebi zayıf olanı koruma düşüncesine dayanmaktadır. Buna yönelik olarak eşlerin dinlenilmesi, sundukları bilgi ve belgelerin incelenmesi önem arz etmektedir. Diğer bir ifadeyle eşler boşanma konusunda anlaşmış olsalar bile bir kez daha bu anlaşma ve sonuçlarını denetime tabi tutma düşüncesi hukukumuzda geçerliliğini korumaktadır.

Ülke gerçekleri göz önüne alındığında boşanma anlaşması yapılırken eşlere tam bir serbesti tanınması ve hâkimin denetiminden tamamen vazgeçilmesinin mümkün olamayacağı düşünülebilir. Gerçekten bir eşin diğer eşin baskısı ve/veya şiddet uygulaması sonucu anlaşmalı boşanmak mecburiyetinde kalması ufak bir olasılık olsa da bu tip durumlar için mahkeme dışı boşanma kurumunun kabul edilmemesi gerekir. Ancak bu istisnai durumlar dışında genel olarak mahkeme dışı boşanma kurumu fayda sağlayacak niteliktedir. Sonuç olarak, toplumsal gerçeklik ve hukuk sistemimiz dikkate alınarak titizlikle yapılacak yasal düzenlemelerle mahkeme dışı boşanma kurumunun ülkemizde de kabul edilebileceği kanaatindeyiz. 


\section{KAYNAKÇA}

Aebi-Müller, Regina/Ziegler, Lenka (2017) "Stand des Scheidungsrechts in der Schweiz": Dutta, Anatol/Schwab, Dieter/ Henrich, Dieter/Gottwald, Peter/Löhnig, Martin (Hrsg.), Scheidung ohne Gericht?, Neue Entwicklungen im europäischen Scheidungsrecht, Bielefeld, Gieseking Verlag.

Akıntürk, Turgut/Ateş, Derya (2019), Aile Hukuku, 21. Baskı, C:2, İstanbul, Beta Yayınc1lik.

Andrup, Henrik/Buchhofer, Bernd/A. Ziegert, Klaus (1980) "Formal Marriage under the Crossfire of Social Change": Eekelaar, John M./Katz, Sanford N. (eds), Marriage and Cohabitation in Contemporary Societies, Toronto, Butterworths, s. 32-38.

Antoloskaia, Masha (2016) "Divorce Law in a European Perspective": Scherpe, Jens (ed), European Family Law Volume III - Family Law in a European Perspective, Cheltenham, Edward Elgar Publishing, s. 41-82.

Antomo, Jennifer (2018) "Reformbedarf bei der Anerkennung von Privatscheidungen", NZFam, s. 243-249.

Biland, Émilie /Steinmetz, Hélène (2017) “Are Judges Street-Level Bureaucrats? Evidence from French and Canadian Family Courts", Law \& Social Inquiry, V:42, I:2, s. 298-324.

Bräm, Verena (2002) "Privatisierung des Scheidungsrechts - ein Holzweg? ": Geiser, Thomas/Koller, Thomas (Hrsg.), Festschrift für Professor Heinz Hausheer zum 65. Geburtstag: Privatrecht im Spannungsfeld zwischen gesellschaftlichem Wandel und ethischer Verantwortung, Bern, Stämpfli Verlag.

Burcuoğlu, Haluk (2004) “4721 Sayılı Yeni Medeni Kanunun Boşanma Düzenlemesinin Eleştirisi ve Uygulamada Karşlaşlabilecek Sorunlar”, Antalya Barosu Dergisi, S: 5/51, s. 40-69.

Ceylan, Ebru (2018) "İsviçre, Fransa, Belçika, İspanya ve İtalya Hukukundaki Boşanma Sebeplerinin Türk Hukukuyla Mukayesesi”, Uyuşmazlık Mahkemesi Dergisi, C:6, S:12, s. 315-334.

Cubeddu Wiedemann, Maria Giovanna/Henrich, Dieter (2015) "Neue Trennungs- und Scheidungsverfahren in Italien”, FamRZ, s. 1253-1259.

Danielsen, Svend (1997) "The Scandinavian Approach: Administrative and Judicial Resolutions of Family Conflicts": Meulders-Klein, Marie Thérèse (ed), Familles et Justice, Brüksel, Bruylant.

Dural, Mustafa/Öğüz, Tufan/Gümüş, Mustafa Alper (2018) Türk Özel Hukuku, Aile Hukuku, C:3, İstanbul, Filiz Kitabevi.

Dutta, Anatol (2017) "Stand des Scheidungsrechts in Deutschland": Dutta, Anatol/

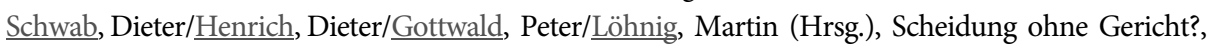
Neue Entwicklungen im europäischen Scheidungsrecht, Bielefeld, Gieseking Verlag.

Dutta, Anatol/schwab, Dieter/吕enrich, Dieter/Gottwald, Peter/Löhnig, Martin (Hrsg.) (2017), Scheidung ohne Gericht?, Neue Entwicklungen im europäischen Scheidungsrecht, Bielefeld, Gieseking Verlag.

Ekşi, Nuray (2012) Milletlerarası Özel Hukukta Medeni Olmayan Evliliklerin ve Adli Olmayan Boşanmaların Tanınması, İstanbul, Beta Yayıncılık. 
Ercan, İbrahim (2014) “Boșanma Davalarında Geçerli Olan Yargılama Ilkelerı”, Süleyman Demirel Üniversitesi Hukuk Fakültesi Dergisi, C:4, S:2, s. 249-269.

Erdem, Bahadır (2006) "Yabancı Aile Hukuku Mahkeme Kararlarının Tanıma ve Tenfizi ile Avrupa Birliği Brüksel II Tüzügü̈”: Şıpka, Şükran/Şensöz, Ebru/Şenol, Ayşe Nilay/Özbilen, Arif Barış (Editörler), Uygulamalı Aile Hukuku Sertifika Programı, Medeni Hukuk ve Milletlerarası Özel Hukuk ile İlişkili Güncel Aile Hukuku Meseleleri 18-20 Kasım 2005, İstanbul, İstanbul Ticaret Üniversitesi Yayınları.

Fankhauser, Roland (2017) Schwenzer, Ingeborg/Fankhauser, Roland (Hrsg.), Fam Kommentar, Scheidung, Band I: ZGB / Band II: Anhänge, 3. Aufl., Bern, Stämpfli Verlag.

Ferrand, Frederique (2017) "Stand des Scheidungsrechts in Frankreich": Dutta, Anatol/ Schwab, Dieter/Henrich, Dieter/Gottwald, Peter/Löhnig, Martin (Hrsg.), Scheidung ohne Gericht?, Neue Entwicklungen im europäischen Scheidungsrecht, Bielefeld, Gieseking Verlag.

Ferrer Ortiz, Javier (2011) "Del Matrimonio Canónico Como Modelo al Matrimonio Civil Deconstruido: La Evolución de la Legislación Española”, Revista Ius et Praxis, V:17, I:2, s. 391-418.

Ferrer-Riba, Josep (2006) "Same-Sex Marriage, Express Divorce and Related Developments in Spanish Marriage Law”, International Family Law, s. 139-143.

Ferrer-Riba, Josep (2012) "Marital Agrreements and Private Autonomy in Spain": Scherpe, Jens (ed), Marital Agreements and Private Autonomy in Comparative Perspective, Oxford and Portland, Oregon, Hart Publishing.

Ferrer-Riba, Josep (2017) "Stand des Scheidung in Spanien": Dutta, Anatol/대wab, Dieter/ $\underline{\text { Henrich}}$, Dieter/ Gottwald, Peter/Löhnig, Martin (Hrsg.), Scheidung ohne Gericht?, Neue Entwicklungen im europäischen Scheidungsrecht, Bielefeld, Gieseking Verlag.

Feyzioğlu, Feyzi Necmeddin (1979) Aile Hukuku, 2. Baskı, İstanbul, Fakülteler Matbaası.

Gençcan, Ömer Uğur (2015) Boşanma Tazminat ve Nafaka Hukuku, 3. Baskı, Ankara, Yetkin Yayıncllk.

Germi, Pietro (Yönetmen) (2011), Divorzio all'italiana, Floransa, CG Entertainment.

Glos, George E. (1983) “The Spanish Divorce Law of 1981", International and Comparative Law Quarterly, V: 32, I: 3, s. 667-688.

Grassinger, Gülçin Elçin (1997) “Boşanma Davasında Eşlerin Boşanmanın Tali Sonuçlarına İlişkin Konularda Anlaşma Yapmaları ve Konu İle İlgili İsviçre Federal Mahkemesi Kararı”, İstanbul Üniversitesi Hukuk Fakültesi Mecmuası Prof. Dr. Türkan Rado’ya Armağan Sayısı 1997, C:LV, S:3, s. 235-242.

Guinchard, Serge (ed) (2008) L'ambition raisonnee d'une justice apaisee, rapport de la Commission sur la Repartition des contentieux remis au Garde des Sceaux, Paris, La documentation française,

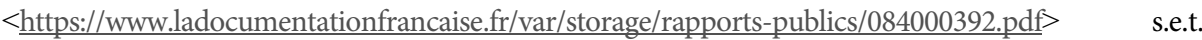
06.10.2019.

Güneș Peschke, Seldağ (2018) “Dijital Boşanmaya ilişkin Güncel Düzenlemeler: Farklı Ulke Uygulamaları”, Kadem Kadın Araştırmaları Dergisi, C:4, S:1, s. 121-146, $<$ http://kadinarastirmalari.kadem.org.tr/wp-content/uploads/2018/08/7.pdff s s.e.t. 06.10.2019. 
Gürsoy, Kemal Tahir (1977) “Eşlerin Anlaşması Suretiyle Boşanma”, Ankara Hukuk Fakültesi 50. Yıl Armağanı 1925-1975, C:2, Boşanma Hukuku Haftası, Ankara, Sevinç Matbaası.

Gürzumar, Aydanur (1991) Die rolle des Richters im Ehescheidungsprozess in der Schweiz und in der Türkei, İzmir, Bizim Büro Basımevi.

Heiderhoff, Bettina (2019), Beck'scher Online Kommentar, Bamberger, Heinz Georg/Roth, Herbert/Hau, Wolfgang/Poseck, Roman (Hrsg.), 50. Edition 01.02.2019.

Huysal, Burak (2017) "Nüfus Hizmetleri Kanunu Kapsamında Yabancı Boşanma Kararlarının Doğrudan Tescili”, Milletlerarası Hukuku ve Milletlerarası Özel Hukuk Bülteni, C:37, S:2, s. 473-507.

Kılıçoglu, Ahmet M. (2002), Edinilmiş Mallara Katılma Rejimi, 2. Baskı, Ankara, Eda MatbaaS1.

Kılıçoğlu, Ahmet M. (2019), Aile Hukuku, 4. Baskı, Ankara, Turhan Kitabevi.

Köprülü, Bülent/Kaneti, Selim (1985/1986) Aile Hukuku, İstanbul, İstanbul Üniversitesi Hukuk Fakültesi Yayınları.

Kristiansen, Jan Erik (1977) "Norway": Chester, Robert (ed), Divorce in Europe, Leiden, Martinus Nijhoff Social Sciences Division.

Martin-Casals, Miquel/Ribot, Jordi/Sole, Joseph (2002) "Grounds for Divorce and Maintenance Between Former Spouses - Spain", <http://ceflonline.net/wp-content/uploads/Spain-Divorce.pdf> s.e.t. 06.10.2019.

Martin-Casals, Miquel/Ribot, Jordi (2008) "The Postmodern Family and the Agenda for Radical Legal Change in Spain": Atkin, Bill (ed), The International Survey of Family Law 2008 Edition, Bristol, Jordan Publishing.

Matthew, J. Mccauley (2011) "Divorce and the Welfare of the Child in Japan", Pacific Rim Law \& Policy Journal, V:20, I:3, s. 589-606.

Moracchini-Zeidenberg, Stéphanie (2018) "La contractualisation de la séparation et de ses conséquences en droit français”, Les Cahiers de Droit, V:59, I:4, s. 1113-1136.

Motozawa, Miyoko (1989) "Die Ehescheidung in Japan:Ehe und Familie im privaten und öffentlichen Recht”, FamRZ, s. 459-465.

Nomer, Ergin (2017) Devletler Hususi Hukuku, 22. Baskı, İstanbul, Beta Yayıncılık.

Oğuzman, Kemal/Dural, Mustafa (1998) Aile Hukuku, 2. Baskı, İstanbul, Filiz Kitabevi.

Oktay Ơzdemir, Saibe (2015) “Tư̈k Hukukunda Boșanma Sisteminde Revizyon Ihtiyacı”, Milletlerarası Hukuk ve Milletlerarası Özel Hukuk Bülteni, C:35, S:1, s. 29-46.

Öncï, Özge (2017) "Eșlerin “Anlașmalı Boșanma” Ç̧̧⿻上丨evesinde Mal Rejiminin Tasfiyesine Yönelik Olarak Yaptıkları Anlassmalar ve Bu Anlașmaların Uygulamada Dogurdugu Sorunlar”, Dokuz Eylül Universitesi Hukuk Fakuiltesi Dergisi, Prof. Dr. Şeref ERTAS’’a Armağan, C:19, Ozzel Sayı, s. 793835.

Özcan, Cem (2019), "Fransız Hukukunda Mahkeme Dışı Anlaşmalı Boşanma”, Legal Hukuk Dergisi, C:17, S:194, s. 647-660.

Özdemir, Nevzat (2003) Türk-İsviçre Hukukunda Anlaşmalı Boşanma, İstanbul, Beta Yayıncllk. 
Özdemir, Saibe (2009) “Boşanma Davalarında Çocuklara İlişkin Kararlar Bakımından Çocuğun Dinlenilme Hakkı”, Prof. Dr. Hüseyin Hatemi’ye Armağan, C:2, İstanbul, Vedat Kitapçllk.

Ơzmumcu, Seda (2014) “Türk Hukukunda Yargitay Kararları Ișı̆ı̆nda Re’sen Araștırma Ilkesi”, Suileyman Demirel Universitesi Hukuk Fakuiltesi Dergisi, C:4, S:2, s. 145-171.

Öztan, Bilge (2015) Aile Hukuku, 6. Baskı, Ankara, Turhan Kitabevi.

Parkinson, Patrick (2011) Family Law and the Indissolubility of Parenthood, New York, Cambridge University Press.

Patti, Salvatore (2017) "Stand des Scheidungsrecht in Italien": Dutta, Anatol/

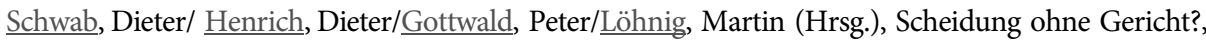
Neue Entwicklungen im europäischen Scheidungsrecht, Bielefeld, Gieseking Verlag.

Rauscher, Thomas (Hrsg.) (2018) Münchener Kommentar zum FamFG, 3. Aufl., München, C.H. Beck.

Reusser, Ruth (1999) “Die Scheidungsgründe und die Ehetrennung”: Hausheer, Heinz (ed), Vom alten zum neuen Scheidungsrecht, Bern, Stämpfi Verlag AG.

Rosenbeck, Bente (2017) “Liberalisation of Divorce”, Scandinavian Journal of History, V:43, I:1, s. 18-39.

Rumo-Jungo, Alexandra (2016) Breitschmid, Peter/Rumo- Jungo, Alexandra (Hrsg.) CHK - Handkommentar zum Schweizer Privatrecht, Personen- und Familienrecht - Partnerschaftsgesetz, Art. 1-456 ZGB - PartG, 3. Aufl., Zürich, Schulthess Verlag.

Ryznar, Margaret/ Devaux, Angélique (2018) "Voilà! Taking the Judge Out of Divorce", Seattle University Law Review, V:42, I: 1, s. 161-183.

Sandström, Glenn/ Garðarsdóttir, Ólöf (2018) “Long-Term Perspectives on Divorce in the Nordic Countries - Introduction”, Scandinavian Journal of History, V:48, I:1, s. 1-17

Saresella, Daniela (2017) "The Battle for Divorce in Italy and Opposition from the Catholic World (1861-1974)", Journal of Family History, V:42, I:4, s. 401-418.

Sarı, Suat (2007) Evlilik Birliginde Yasal Mal Rejimi Olarak Edinilmis, Mallara Katılma Rejimi, Istanbul, Beşir Kitabevi.

Saymen, Ferit H. (1950) Aile Hukuku Dersleri, 1949-1950 yılı takrirleri, İstanbul, Teksir İşleri.

Scalzini, Giorgio (2016) "Ehetrennungen und Ehescheidungen auf administrativem Wege in Italien- ein Überblick über die wichtigsten Reformen", StAZ Das Standesamt, s. 129-131.

Schmidt, T. Svenné (1984) "The Scandinavian Law of Procedure in Matrimonial Causes": Eekelaar, John M./Katz, Sanford N. (eds), The Resolution of Family Conflict - Comparative Legal Perspectives, Toronto, Butterworths, s. 77-98.

Seçer, Öz (2016) “Anlașmalı Boșanmada Eșlerin Yaptıkları Anlașma”, Inönü Universitesi Hukuk Fakuiltesi Dergisi, C:7, S:2, s. 259-286.

Seçer, Ơz (2009) "Isviçre ve Türk Hukuklarında Anlaşmalı Boșanma ve Fiili Ayrılık Sebebiyle Boșanma”, Bahçeșehir Universitesi Hukuk Fakuiltesi Kazancı Hakemli Hukuk Dergisi, S: 63-64, s. 39-70. 
Sperr, Anneken Kari (2017) "Stand des Scheidungsrechts in Norwegen": Dut-

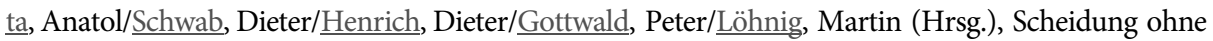
Gericht?, Neue Entwicklungen im europäischen Scheidungsrecht, Bielefeld, Gieseking Verlag.

Sutter, Thomas/Freiburghaus Dieter (1999) Kommentar zum neuen Scheidungsrecht, Zürich, Schulthess.

Sverdrup, Tone (2002) "Grounds for Divorce and Maintenance between Former Spouses Norway”, <http://ceflonline.net/wp-content/uploads/Norway-Divorce.pdf> s.e.t. 06.10.2019.

Şener, Esat (1977) “Medeni Kanunun Aile ve Nesep Bölümünde Çatışan Eğilimler”, Ankara Hukuk Fakültesi 50. Yıl Armağanı 1925-1975, C. 2, Boşanma Hukuku Haftası, Ankara, Sevinç Matbaası.

Şensöz Malkoç, Ebru (2017) Aile Hukukuna Ilişkin Yabancı Kararların Tanınması, Istanbul, On İki Levha Yayıncılık.

Şıpka, Şükran (2007) ““'Hukuk Uyuşmazlıklarında Arabuluculuk Kanunu Tasarısı”nın Değerlendirilmesi”, Istanbul Ticaret Universitesi Sosyal Bilimler Dergisi, C:6, S:12, s. 163-175.

Tanrıbilir, Feriha Bilge (2019) "Türk Hukukunda Yabancı Makamlarca Verilen Boşanma Kararlarının Tanınmasına İlişkin Gelişmeler”: Doğan, Vahit/Ayhan İzmirli, Lale/Yılmaz, Alper Çağrı (Editörler), Milletlerarası Özel Hukukta Güncel Meseleler Sempozyumu, Ankara, Savaş Yayınevi.

Tekinay, Selahattin Sulhi (1982) Türk Aile Hukuku, 4. Baskı, İstanbul, Fakülteler Matbaası.

Trempel, Eberhard J., (2011) “Die Grundzüge des Ehe- und Scheidungsrechts Japans”, $<$ http://trempel.de/international/japan/index.php?TSPD 101 R0=b518cfc4ed66d6deb64c0e6792c9e 5bbro70000000000000000e2f20f5fffff00000000000000000000000000005ce3dd $91003 \mathrm{~d} 2870 \mathrm{f} 5>$ s.e.t. 06.10.2019.

Tütüncübaşı, Uğur (2017) "Yabancı Kararların Türk Hukukunda Tanınması Konusunda 690 Sayılı Kanun Hükmünde Kararname İle Düzenlenen Yenilikler”, Dokuz Eylül Üniversitesi Hukuk Fakültesi Dergisi, C:19, S:2, s. 103-128.

Uyanık Çavuşoglu, Ayfer (2006) Türk Milletlerarası Özel Hukukunda Boşanma, İstanbul, Beta Yayıncilı.

Velidedeoğlu, Hıfzı Veldet (1954) Türk Medeni Kanununa Göre Medeni Hukuk, Başlangıç- Şahıslar, Aile, Miras ve Eşya Hukuku (Ayni Haklar), İstanbul, İstanbul Matbaacılık.

Yılmaz-Bilgin, Esra Pınar (2016) Türk Hukukunda Anlaşmalı Boşanma, Istanbul, On İki Levha Yayıncilik.

Zevkliler, Aydın/Acabey, M. Beşir/Gökyayla, K. Emre (2000) Zevkliler Medeni Hukuk, 6. Baskı, Ankara, Seçkin Yayıncılık.

Zeytin, Zafer (2017) Edinilmis, Mallara Katılma Rejimi ve Tasfiyesi, 3. Baskı, Ankara, Seçkin Yayincilik. 